Portland State University

PDXScholar

$5-6-1994$

\title{
The Development of Natural Law from Plato to the Renaissance
}

James M. Harrison

Portland State University

Follow this and additional works at: https://pdxscholar.library.pdx.edu/open_access_etds

Part of the History Commons

Let us know how access to this document benefits you.

\section{Recommended Citation}

Harrison, James M., "The Development of Natural Law from Plato to the Renaissance" (1994).

Dissertations and Theses. Paper 4849.

https://doi.org/10.15760/etd.6725

This Thesis is brought to you for free and open access. It has been accepted for inclusion in Dissertations and Theses by an authorized administrator of PDXScholar. Please contact us if we can make this document more accessible: pdxscholar@pdx.edu. 


\section{THESIS APPROVAL}

The abstract and thesis of James M. Harrison for the Master of Arts in History were presented May 6, 1994, and accepted by the thesis committee and the department.

COMMITTEE APPROVALS:

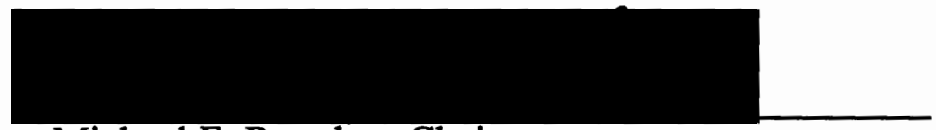

$$
\text { Michael F. Reardon, Chair }
$$

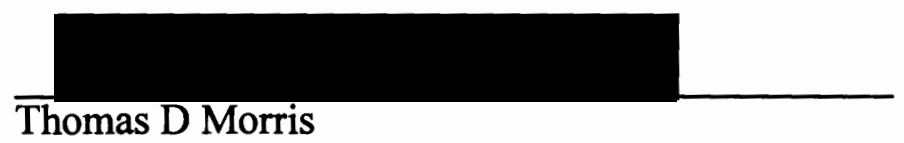

DEPARTMENT APPROVAL:

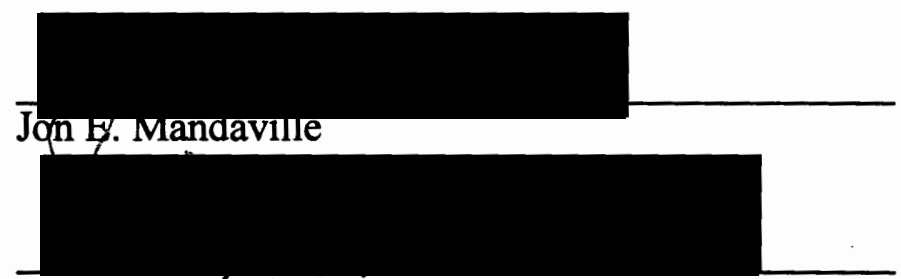

Larry S. Bowlden

Representative of the Office of Graduate Studies

David A. Johnson/Chair

Department of History

ACCEPTED FOR PORTLAND STATE UNIVERSITY BY THE LIBRARY

by on

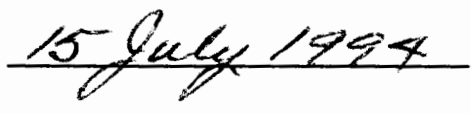




\begin{abstract}
An abstract of the thesis of James M. Harrison for the Master of Arts in History presented May 6, 1994.
\end{abstract}

Title: The Development of Natural Law from Plato to the Renaissance.

The development of natural law has had a profound influence on the course of European civilization. I have started my research with natural law as it was conceived by Socrates and Plato. I then followed the major developments and changes that occurred to this original design through to the height of the Renaissance in the Sixteenth century. I relied mostly on secondary sources for several reasons. First the translations of the original materials are all well established. This includes translations of Plato, Aristotle, Aquinas, Ockham, Suarez, Luther, as well as others. Secondly, and more importantly, the emphasis of my research was not to describe the secondary and tertiary intellectual work of the thinkers after Plato. Rather I wish to show how the philosophical forces that Plato struggled against during his lifetime reemerged later in two major philosophies peculiar to Europe and how these essentially distorted his original design. 


\title{
THE DEVELOPMENT OF NATURAL LAW FROM PLATO TO THE RENAISSANCE
}

\author{
by \\ JAMES M. HARRISON
}

A thesis submitted in partial fulfillment of the requirements for the degree of

\author{
MASTER OF ARTS \\ in \\ HISTORY
}

Portland State University

1994 


\section{TABLE OF CONTENTS}

CHAPTER

PAGE

I INTRODUCTION 1

II THE ORIGINS OF NATURAL LAW 6

PLATO'S DEFINITION OF THE TERM "NATURE" 7

THE FIVE DEFINITIONS OF NATURE IN PLATO'S DIALOGUES 8

Nature as a normative world order $\quad 8$

Nature as the eidetic structure of concrete entities $\quad 10$

Nature as formally determined tendency 11

Nature as the correct ordering of incipient tendency $\quad 14$

$\begin{array}{ll}\text { Nature as existential fulfillment } & 16\end{array}$

The Concept Of Forms In Natural Law 19

Plato's Realm of Forms $\quad 21$

CONCLUSION 34

III FOLLOWING THE COURSE OF NATURAL LAW 36

Platonic Philosophy and Islam $\quad 38$

Natural Law at the Dawn of the Renaissance $\quad 41$

Natural Law in the Renaissance $\quad 45$

The Enemies of Natural Law $\quad 47$

CONCLUSION 61

IV THE MUTATION OF NATURAL LAW 63

Nominalistic Thought During the Renaissance 66

The Effects of Nominalism During the Renaissance 69 
CONCLUSION: STANDING AGAINST THE WORLD

$\mathrm{V}$ THE CONSTANCY OF NATURAL LAW

Platonic Answers

CONCLUSION 86

BIBLIOGRAPHY 


\section{CHAPTER I}

\section{INTRODUCTION}

The story of the course of natural law since its recognized beginning with Socrates and Plato nearly twenty-five centuries ago is a story of the course of European and Mediterranean civilization.

In choosing the word "course" I mean to suggest just that; not evolution or development of natural law. There is an assumption in both these latter terms. If we accept the origins of natural law as found in the Platonic dialogues and I mean in a holistic way (not natural law as it has come to be defined in the past one hundred and fifty years), and then follow its course we cannot suggest that it developed, not given its foundation and the design of its chief architect. To develop means to follow a determined route to an end point. The term evolution, though not as teleological in connotation as "develop", has other implications. In any definition other than the strict biological one "evolution" is very close to the other term "develop". If anything, the biological sense of the word is closest to what has occurred with natural law: "The continuous adaption of an organism to the environment by the integrating agencies of selection, hybridization, inbreeding and mutation."

I am not trying to open a large family-sized can of worms on issues of historiography. But I am here calling into question the linear concept of history. Simply because twenty-five centuries have passed does not mean that an entity has evolved or developed. Indeed, staying with the biological definition of "evolution" we can just as 
easily ask if this entity has so mutated over time that it needs to be reclassified. Perhaps it has even devolved or branched off to a dead end?

I asked these questions as I took graduate level courses in the history of U.S. Constitutional law as well as European intellectual history and diplomatic history. Why was there such confusion over what constitutes natural law, especially if this is the basis of our Constitution?

Most of my research during my graduate studies dealt either directly or indirectly with this subject. Over and over the research kept pointing back to Socrates and Plato. As I looked further, I began asking the obvious questions. If we know that the concept of natural law began with and was clearly defined by these two philosophers, then what happened in the intervening centuries to change it? More importantly, why did it change? I can only say that my research has not been easy. On the contrary it has been a very arduous journey.

From the starting point of Socrates and Plato the course of natural law changed almost immediately. This occurred with Aristotle. He rejected Plato's concept of Forms, which is the foundation of Plato's philosophy. From here the course splits and follows several routes. I have tried to focus on the main ones -- those that have (seemingly) had the largest historical effect on this issue. Still the task of following these courses was difficult. What was of great help was the framework in which I set the issue.

I believe that the most enduring aspect of human existence is Thought. It is thought that conceives and builds great edifices. It is ideas that weld peoples together and which create a society. Thought propels civilization to either great heights or great chasms. It 
must be understood that by the term thought I don't mean the daily flotsam and jetsam of mental activity. And even though -- far too often -- it seems that people react instinctually instead of intelligently, producing (also far too often) horrible results, we are, like it or not, rational creatures. With this said, we can step into the idea that a group of people is bound together by some degree of a unity of thought.

Given this foundation the course of natural law cannot be viewed as a meandering concept disconnected from anything more substantial than the existing mesocosm of the time. ${ }^{1}$ The axiology of a race informs all significant patterns of thought. It is the foundation upon which theories, philosophies, concepts are raised.

If we view axiology as the foundation of a house, or better yet, as the foundation of a palace, then the philosophies and ideologies developed would be the actual structure resting on that foundation. Regardless of what remodeling may be done over time, even to the extent that the structure is so changed as to barely resemble the original, it still is restricted by the foundation upon which it rests. In other words, a great deal can change about the palace, but all changes are finally constrained and determined by the reality of the foundation.

Consequently the questions I have asked regarding this issue are four: 1) what was the original definition of natural law as it was conceived by Plato; 2) what were the major changes in this concept; 3) what were the causes of these changes, and 4) what

${ }^{1}$ Mesocosm is a term used by Joseph Campbell to describe the entire cultural spectrum of a people at any given time. While it is tied to the axiological foundation this mesocosm is susceptible to the flux of human life in a way that the axiology is not. JMH 
happened to natural law during the Renaissance that changed it completely down to the present.

This last question is important in a number of ways. Not only was the period known as the Renaissance the progenitor of the modern age, but it was also the major rift separating the ancient world from what we casually term the modern. In this connection this was also the period that was the originating impulse for the Constitution of the United States.

The Declaration of Independence as well as the Bill of Rights are both supposedly founded on natural law. But this is the "natural law" of the Enlightenment. Despite the hearkening back to the golden age of the ancients with a plethora of references found in the political writings of the times, (e.g. The Federalist Papers of Hamilton, Madison and Jay), the natural law referred to was little more than a shadow of what Plato had first purposed.

How then could something which stands as the foundation of not only our government but also our very conception of ourselves as a civilization be so far removed from a working reality? How could it become the vague concept that it has come to be? This is the question that motivated me to discover what had happened to Plato's natural law. To this end, I have constructed this thesis in the following way:

First I will attempt to explain the Platonic conception of the word Nature, from which the more technical term natural law springs. From this I will examine Plato's concept of Forms -- which is the foundation of Platonic thought. I hope to show how natural law and the concept of Forms are elements of the same overarching structure. 
Lastly, in this section I will briefly examine Plato's concept of justice as it relates to natural law and Form.

From this start I will trace some of the major junctures along the course that natural law has taken over the past twenty-five centuries. This includes an examination of the reintroduction of Aristotle to Europeans via the Muslims of Spain in the late twelfth and early thirteenth centuries. Included in this section is a focus on William of Ockham, a near contemporary of St. Thomas Aquinas. Next I will examine how all these varied elements came together in the Renaissance. Specifically, I will examine how the Spanish Thomists struggled to save the last vestiges of via antiqua from the forces of the Reformation, the Humanists and the Machiavellians.

While I will attempt to show the historical forces that brought about this series of confrontations I am more interested in showing how these forces could have been created in the first place. It is my contention that they were not accidental -- that they did not just evolve in a simple linear manner. The philosophy of materialism that developed in Europe has been the defining influence in the shaping of what we have come to know as natural law in the past four centuries. 


\section{CHAPTER II}

\section{THE ORIGINS OF NATURAL LAW}

The concept of natural law finds its beginning in Socrates and Plato. The actual term "natural law" appears only a few times in Plato's dialogues. 2 Wild points out that often, especially in the history books of the last century, the Stoics were credited with formulating the theory of natural law -- based primarily on philological considerations. ${ }^{3}$

For the Greek mind the universe held a rational order. ${ }^{4}$ This is not to reject religion and its role in Greek life, but there was an insistence by the Greek mind to discover harmony in the universe. Religion and religious sentiment, though pervasive at various times, did not deter the likes of men such as Pythagoras, who sought to bring religion and philosophy to a greater unity, or Xenophones (who openly opposed religion) from seeking this rational order. 5

That nature has some rational order was not really contended by the Greek philosophers. What that nature was, and whether there was purpose associated with it was another point entirely. There is not space here to go into the variations of thought concerning nature. For our purposes the division between materialism and realism can

2 John Wild, Plato's Modern Enemies and the Theory of Natural Law (Chicago: The University of Chicago Press, 1971$)$, p. 136.

3 Ibid., p. 135.

${ }^{4}$ Sir Ernest Barker, Greek Political Theory (New York: Barnes \& Noble, 1961), pp. 2-3.

5 J. Burnet, Early Greek Philosophy (London: Adam \& Charles Black, 1945), p. 80. 
best be exhibited by briefly examining Plato's definition of nature in its different functions.

\section{PLATO'S DEFINITION OF THE TERM "NATURE"}

What does Plato mean when he uses the term nature? This term, unlike the more narrowly defined "natural law" or "law of nature" is used extensively by Plato. ${ }^{6}$ For Plato nature refers to the entire world order of mutually supporting forces and tendencies. Here nature does not mean what it has come to mean in especially the past century and a half, i.e., a mechanism devoid of purpose or meaning. Plato's definition of nature is multiple. For Plato the changing entities of this world have structure and often Plato uses the term "nature" to refer to this aspect of an entity. He is specifically making reference to Form or eidos (idea) of this individual thing. ${ }^{7}$ Nature, in this sense, is imperfect and incomplete. But this does not imply that it is static These incomplete Forms tend toward the completion of themselves. They are, in other words, tendential.

This concept of tendency is for Plato and Socrates one of the central proofs of a rational universe. It is important to understand their definition of the term rational universe. While it was clearly recognized that much of the world was non-rational, i.e. there was no active, participating rational intelligence in animals and plants, Man was looked upon as something apart from this non-rational world by the existence of his

\footnotetext{
${ }^{6}$ Wild, p. 150.

7 Ibid., p. 150.
} 
mind. Yet all life has a nature to fulfill. Such fulfillment, according to Plato is good. To be thwarted in the attempt to complete this nature is evil. 8

\section{THE FIVE DEFINITIONS OF NATURE IN PLATO'S DIALOGUES}

According to John Wild, there are five definitions of the term nature in Plato's dialogues. These five are as follows: 1) the normative order of the world as a whole; 2) the determinate structure of a finite entity; 3 ) the dynamic tendency of such an existent entity; 4) the ordered process by which it attains some degree of fulfillment, and 5) the valuable or authentic conditions of such fulfillment. 9

\section{A. Nature as a normative world order}

The term nature is, according to Wild, used throughout the dialogues to refer to the changing events of the world of nature. In the Protagoras $315 \mathrm{c} 510$ there is a discussion of astronomy as a "natural science." In the Phaedo $103 \mathrm{~b}^{11}$ we are told that even though the world is in flux, it is not without structure or form. Here Plato is referring to two Forms, e.g. Socrates is tall in comparison to $\mathrm{X}$ but short in comparison to $\mathrm{Y}$. The conclusion here without going into the whole argument is that something doesn't share

8 For further examination of this point beyond what will follow here I would suggest to the reader an examination of A.E. Taylor's book, Aristotle, specifically p. 52. Also Richard Patterson, Image and Reality in Plato's Metaphysics, p. 165., Appendix 1. This deals with Plato's Phaedo 74-75. See also the issue of the inferiority of sensible Forms as compared to the Form on p. 87.

9 Wild., p. 138

${ }^{10}$ Edith Hamilton and Huntington Cairs, ed., The Collected Dialogues of Plato (Princeton, N.J. Princeton University Press, Bollingen Series LXXI, 1989), P. 314. Please note that all references to Plato's writings will be found in this edition.

${ }^{11}$ Hamilton, p. 84 
two opposing Forms simultaneously, but rather as one "retreats" the other "gains". 12 In other words something is not both ugly and beautiful at the same moment; rather the object is becoming more beautiful or is becoming less beautiful in relationship to the Form Beauty, as determined by the nature of this object. This last point we will examine further. First, let us return to Plato's use of nature in reference to a normative world order.

In Book X of the Laws Plato "gives us his most explicit statement of [his] theory of natural law." 13 It contains a complex argument for the priority of rational life over lifeless matter as the first moving principle or nature of the cosmos. We are told that the materialists wish to identify this principle with earth, or air, or fire. But they do not use the term rightly since as a matter of fact soul or life is the first moving principle, and therefore "in a special sense exists by nature." [Laws $892 \mathrm{~b}-\mathrm{c}$ ] This rational living principle of natural order is God. Moved by the materialistic doctrine of might makes right, men commonly say that law should have no regard for virtue, but only for power and preservation. This is held to be "the definition of justice which is really founded on nature" [Laws 714c3-715a]. 14

Indeed, Plato and Socrates' main concern was to counter the philosophy of the materialist, which they saw as destructive to human life. In Book IV of the Laws Plato again argues against the materialists who contend, to varying degrees, that might makes right. Plato refers to nature as being directed by God, and that justice attends Him.

But then, in conscious opposition to this physicalist conception of nature, Plato gives his own answer. "God, as the ancient saying has it, holding the beginning, the middle, and the end of all beings, moves in a straight path according to nature and justice always attends Him," (Laws, see note 13). This cosmic order of nature carries its own norms within it. That which follows these norms achieves some degree of fulfillment. That which deviates is eliminated, In the case of men who are capable of exercising choice in the matter, those who would be happy must order their lives in accordance with natural law: those who seek power in the madness of the hubris are justly punished by frustration and destruction. [Laws 716] Here is a clear expression of Plato's conception of a moral law founded on the very nature of things and thus enforced by natural sanctions. Nature

\footnotetext{
12 A.E. Taylor, Plato: The Man and His Work, (Cleveland, Ohio: Meridan Books, 1952) pp. 204-205.

13 Wild., p. 139.

14 Ibid., p. 138.
} 
determines what modes of being are good for a thing, whatever it may be, and also their order of greater or lesser importance. Thus, wealth is to be sought "only for the sake of the body, and the welfare of the body for the sake of the soul; and this order of subordination exists by nature," [Laws 870b4-5] 15

\section{B. Nature as the eidetic structure of concrete entities}

In the Timaeus 50, Plato speaks of the concrete objects of the world as composite. Each of these composite objects is a mixture of "something vague and indefinite, with something fixed and determinate." 16 Wild states that in this sense nature is equivalent to the essential Form (idea) which, "makes each concrete entity what it is." 17

In the Republic 598al the question is raised as to whether the painter attempts to represent each thing as it is "in its very nature" or in its pure structure. If so, he would be a scientist or a philosopher. But this is not the case. The purpose of the artist is different. He is trying to represent the concrete existent with all its individual qualities and peculiar accidents. Here nature is being used to refer to the pure form, or idea as Plato calls it. Individual entities only imitate or participate in these forms which are never perfectly present. But the finest examples of concrete things come sufficiently close so that they may suggest their archetypes to the discerning intellect.

Thus, in the myth of the Phaedrus, when the charioteer sees a very beautiful object (254b) he is reminded of "the nature of the beautiful," the pure idea of beauty itself. In the Philebus (25a) we are told that when we see the similarities of those existential factors which are subject to more or less, we gather them all together and impress on them the seal of a single nature. There are many other instances of such usage in the dialogues. 18

So nature here means the determinate structure of the object. But there are other factors involved with regard to the nature of the composite (finite) things. 19

$$
\begin{aligned}
& 15 \text { Ibid., p. } 139 . \\
& 16 \text { Ibid., p. } 140 . \\
& 17 \text { Ibid. } \\
& { }^{18} \text { Ibid., pp. 140-141. } \\
& 19 \text { Richard Patterson, Image and Reality in Plato's Metaphysics, (Indianapolis, Indiana: Hackett Publishing } \\
& \text { Co., 1985) pp. 40-42. }
\end{aligned}
$$




\section{Nature as formally determined tendency}

For Plato the definition of nature just given is only partial. There are other structural elements of an object's nature other than (strictly) its Form. In the Phaedrus 270d-e Socrates speaks of understanding the nature of a thing, whether it is simple or complex, and if complex, "to enunciate its parts. .." Plato quite often, in light of this definition, connects nature with change. In the Laws $892 \mathrm{c}$ Plato is arguing against what he considers three heresies which should not go unchallenged. These are atheism, Epicureanism 20 and the very worst of all, that one can sin against God and escape the consequences by giving gifts and offerings. What does this have to do with nature in this context? As Taylor explains ${ }^{21}$ Plato sees these concepts as a ravenous disease, literally pulling the fabric of the soul apart. All three reject the notion that there are natural consequences in running counter to our nature. Each of these destroy the foundation of human civilization by introducing, in their own way, subjectivism into human society. In these concepts the nature of an entity cannot be defined, and so what is best for the entity can never be determined. This allows a human to behave in whatever manner he desires, since humans are rational and capable of escaping the restrictions placed upon nonrational creatures by their nature. This, as Socrates and Plato saw it, was disastrous for human society, since humans could behave like animals, but with far graver consequences. So for Plato, to not recognize or reject nature as a tendential element moving an entity toward greater perfection of that very nature is devastating.

"As we have seen, no doctrine is more essential to the philosophy of natural law than that of the unfinished or tendential character of finite existence. There is hardly a page in Plato which does not either explicitly express or imply this doctrine. It is perhaps most

\footnotetext{
20 It should be noted here that while Epicures came after Plato (341-270 B.C.) this remark, which is taken from Taylor, is referring to the lifestyle that has come to be known by this designation. JMH

21 Taylor, pp. 490-491.
} 
strikingly asserted in a well-known passage of the Phaedo [75] which has attracted the attention of many commentators." 22

A centrally crucial element of Plato's definition of nature is the role of Form to the sensible entity. We have so far only touched briefly on this matter, but it is without a doubt the foundation of Plato's concept of natural law. The nature of an entity is tendential because it is in the process of participating (increasingly) in the Form(s) which informs its essence. Unlike the atheist or epicurean who views the nature of a thing as static -- simply in existence with no essential purpose, this definition of nature recognizes that all entities are in the process of becoming. For Plato they are becoming a greater (or lesser) manifestation of the Form(s).

According to Plato then, pure Form, such as Justice or Beauty, does not reside in a concrete entity rather the entity participates 23 in the Form. In an analogy that more clearly demonstrates what Plato means by participation we can review the Republic 508bd. The analogy is of the sun. The sun is the Good from which all other Forms emanate. We will revue this analogy later.

The emphasis of this passage, as well as numerous others, is that all finite entities are in the process of (tending toward) fulfilling their nature. That nature, in this respect, is the capacity of an entity to manifest or reflect the Forms (or attributes).

The imperfect forms of actual entities are ever striving to complete themselves. The word nature is often used not only for structure but also for the dynamic tendencies determined by this structure. Thus in the interesting passage of the Phaedrus [270d] to which we have already referred, Plato tells us that in studying any nature we must first try to understand its pure eidetic structure and then the active and passive powers

22 Wild, p. 141-142.

23 The issue of "participation" and how Plato actually felt about this analogy, while of some importance, is not critical to the focus of this paper. JMH 
determined by this structure, how it acts and how it suffers "by nature." Such a natural tendency may be thwarted and distorted, but it cannot be wholly eliminated, for as we are told in the Timaeus [62b] what is, for example, contracted against nature fights to free itself from obstruction in accordance with nature. The nature of every being disposes or fits it for certain acts which fulfill this nature. Thus justice is defined in the Republic [433a6], as rendering to every man his due, or enabling him to practice "that for which his nature is best fitted. 24

The world then is not chaotic, which is how Plato asserts the materialists (including the atheist, epicurean, etc) philosophies would have it. There are, according to Plato, subrational and rational tendencies. The sub-rational tendencies are "regular sequences determined by recurrent tendencies." 25 Thus a horse will always generate a horse even if the new-born is deformed. Indeed, a deformation would be seen as a thwarted tendency in the nature of the formation of the horse. But despite the deformation, it is still a horse genetically. ${ }^{26}$ Speaking of humans as rational creatures Wild continues with Plato's definition:

Human tendencies, however, do not work in this automatic way. They are subject to spontaneous rational control, which may obstruct or distort the basic tendencies of nature through ignorance or intemperance. Nevertheless, these basic tendencies cannot be entirely eliminated. As opposed to incidental desires, there are certain necessary needs for food and drink which must be realized to some degree if human life is to be lived at all. They cannot be escaped. Also, if pursued under rational control, they are not only apparently but really beneficial. We pursue such tendencies by "a necessity of nature," [Republic 558d-e]. The same distinction plays an important role in the argument of the Phaedo, which is often interpreted as advocating the most extreme and unqualified asceticism. This however is not the case. The philosopher does not despise material things as such, but only "in so far as there is no great necessity of having them" [Phaedo $64 \mathrm{el}$; c.f. e5, 67a3-4, and 83b7]. 27

\footnotetext{
24 Ibid., p. 142.

25 Ibid., p. 142.

26 See Plato's Cratylus 393c-394d, Also the Laws 932a

27 Ibid., p. 143.
} 
There are other human tendencies as well. The most important of these is the "cognitive urge." 28 These tendencies can be ignored or distorted also, but they too can never be wholly eliminated.

"'By its very nature every human soul beholds real being." [Phaedrus 249e]. Reason is clearly the most accurate and comprehensive of all our cognitive faculties. Ordinarily it is suppressed or weakened by neglect. Nevertheless by nature it is the ruling faculty. Reason alone can lead us to the human good." 29

\section{Nature as the correct ordering of incipient tendency}

For Plato virtue is a universal ontological category not restricted to man. ${ }^{30}$ All of existence is ordered and thus all parts of this existence are also ordered, i.e. each entity does what is fitting for it to do. ${ }^{31}$ The ordered existence will not sanction any of its parts from fulfilling its natural capacity. ${ }^{32}$

Just as there is a right course to follow, so also, according to Plato, there are contrary courses which can be chosen and which distort and weaken the tendency of the soul toward virtue. ${ }^{33}$ In these passages just noted, especially the last two, this concept is expanded further. In the Meno 78c Socrates states that the "power of acquiring good

\footnotetext{
28 Wild. p. 143.

29 Ibid.

30 Ibid.

31 See Plato's Laws $903 \mathrm{~b}$.

32 Wild., p. 143. See also Plato's Republic 517a and 577c.

33 See Plato's Laws 906a; Meno 78c; Gorgias 506d5.
} 
things. . . is virtue." 34 In the Gorgias 506d5 Socrates asks Callicles to admit to the apparent fact that the "goodness" of any entity does not come to that entity by accident:

But the goodness of ourselves and of all other good things is due to the presence of some excellence? That seems necessarily true, Callicles. But surely the goodness of anything, whether implement or body or soul or any living thing, does not best come to it merely by haphazard, but through a certain rightness and order and through the art that is assigned to each of them. Is it so? I certainly agree. Then the goodness of anything is due to order and arrangement? I should agree. It is then the presence in each thing of the order appropriate to it that makes everything good? So it appears to me. ${ }^{35}$

So for non-cognitive beings this ordering is automatic. It is constantly operational in nature. Humans, though, as rational beings, can participate consciously in many elements of their tendential nature. ${ }^{36}$ Humans make moral choices: whether to act justly or unjustly, with kindness or hate, etc. So in the Republic $435 \mathrm{e} 2$ where Socrates is referring to the qualities he wishes the state to have, he links this with the state's citizens and the virtues they have through Form and habit. In Plato's reference to nature in this term, Wild insists that Plato means to prove that nature orders tendencies toward a virtuous end.

The mode of ordering initial tendencies which is fitting, proper, and right is one which agrees with the needs of nature. Hence, at both the subhuman level and the human level those virtuous acts which ought to take place are constantly described as being in accordance with nature, each nature having its proper virtue. Thus, we are told that "the first shoot of any plant being well advanced at the very beginning towards the virtue of its own nature has an advantage on reaching maturity, and this is true of other plants, of wild and tame animals and of man." [Laws 765e].

In the case of man, certain of his tendencies are more important than others, goods of the body being subordinate to goods of the soul, and all to the supreme virtue of

34 This whole passage has Socrates leading Meno, a young slave, in distinguishing what virtue really is. See also Taylor, Plato, p. 135.

35 Gorgias, p. 289.

36 Wild., p. 144. 
wisdom. This is not an arbitrary order but one which has been determined by nature. [c.f. Laws 631d1-2] Right action is described as agreeing with nature. 37

\section{E. Nature as existential fulfillment}

The last definition of nature, linked closely with what we've examined above, is to understand the distinction between virtue and goodness. While these two are impossible to separate, yet there is a distinction, which will become clear as we continue with Wild.

For Plato, goodness or value is an ontological category applying to all existence, and is by no means restricted to man. Its primary mark is sufficiency. The good, we are told, "is sufficient and complete and such as to be sought by all plants and animals which could live in this way all their lives." [Philebus 22b] It is important to notice here that the goodness of living creatures is not a fixed state ever to be finally reached, for their life is a process. Such a fixed state would be death. The good of a finite creature is rather a way of life, penetrating through the whole of the process. 38

Plato sees life as a series of progressive stages of development. The more an entity fulfills its capacities the better it is. "Goodness is the realization of tendency." 39 God alone is perfect. 40 All other creatures are subject to limitation. Limitation though does not equal evil for Plato (as it seems to be viewed later in Christian theology). 41

\footnotetext{
${ }^{37}$ Ibid

${ }^{38}$ Wild., p. 145.

39 Ibid., p. 146.

${ }^{40}$ Republic, 380-381c.

${ }^{41}$ There are a few passages in the Laws that would seem at first glance to oppose the assertion that Plato did not view limitation as evil. Wild speaks to this. (p. 146).
} 
So value is the fulfillment of natural tendency. Evil is the willful obstruction and frustration of such tendency. This obstruction of tendency is always referred to in negative "or privative terms" 42 Injustice causes a man or society to be at odds with themselves. 43 Even the term "honor among thieves" is a recognition of this fact. An outlaw gang could not operate effectively as a team without some element of justice existing among them. 44

Evil is always the privation of some good. The possession of money and material things is good. The corresponding evil is poverty. Health is the good of the body. Its evil is disease and deformity. Virtue is the health of the soul. Vice is injustice and the lack of knowledge. Good and evil are existential categories. To exist in a condition of realization and fulfillment is good. Evil is nonexistence and destruction. ${ }^{45}$

Each entity must fulfill (realize) its capacities. But it must be remembered that each entity also has its own peculiar nature. The "good" for one entity is not necessarily the good for another. Goodness then is not just fulfillment of capacity but fulfillment of a particular capacity. ${ }^{46}$ It is also important to note that the good is not to be confused with our opinions and hopes.

We are in no position to legislate what is really good and bad. This humanistic pride is a delusion of utilitarianism. It is nature that first legislates independent of all arbitrary human decree. Hence, throughout the dialogues this word is used to suggest what is really sound and healthy as opposed to our subjective opinions and desires. The pragmatic followers of Protagoras are ready to grant with respect to what is merely advantageous for a state, that one counselor may be better than another. But when it comes to the ultimate questions concerning goodness and justice they collapse into relativism and stubbornly assert that "no one of these has by nature an essence of its own, but that the common opinion of men is true when it is adopted, and remains true as long as it is held," [Theaetetus 172b] In the Cratylus [387a] Plato writes: "actions are performed

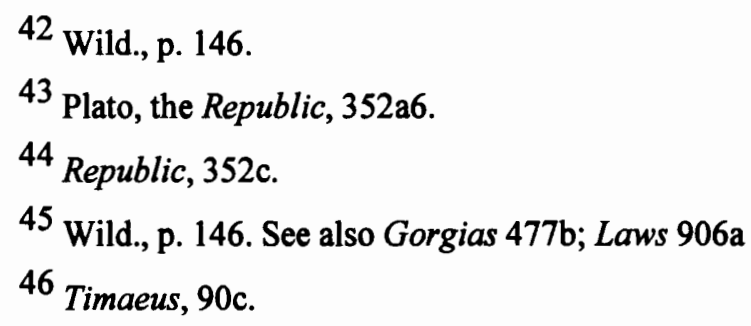


according to their real nature, and not according to our opinion." In these and many other passages the word nature is used in a realistic sense, to mean what actually exists as opposed to our subjective opinions and desires. Real goodness has nothing to do with our wishes. 47

How are we to determine the real nature of any entity? Plato's answer is to search out the qualities, Forms, or attributes of this entity and compare them against the best standard available of these attributes. In the Philebus (44e) he describes this search with regard to the quality of hardness. Since all entities are in the process of change, tending toward a greater acquisition of the attributes determined by their nature, we must look for the most intense display of those qualities.

Human nature will be observed at its best in those individuals who have pushed their capacities to the very breaking point. Here we shall find the most complete and authentic human life. But we must be on our guard against fiction and pretense. We must penetrate through outward display to what is really there in nature, looking for situations in which the tendency is able to display itself in act spontaneously, from the agent himself. 48

Wild completes his analysis of Plato's five definitions of the term nature, and specifically with regard to the close connection of virtue and goodness with the following:

In the light of this analysis, we may attempt to cast some light on Plato's conception of the intimate relation between virtue and goodness. On the one hand, they are distinct, and yet on the other hand, so closely fused together that he often seems to speak of them as though they are one. The meaning of this should now be intelligible. Good and evil are not to be analyzed in terms of formal structure (properties and qualities) alone. They are rather dynamic modes of existence with a temporal history. Thus, human good and evil begin as incipient tendencies and "spring from the soul. . . flowing out from thence. .." into the fulfillment or deprivation. [Charmides 156e] The right ordering of these first tendencies in accordance with nature is virtue -- the chief cause of good. But goodness is fulfillment -- the actual being and full possession of realization. [Symposium 205-206]. Virtue is the chief cause of good. But owing to the limitations of human

$$
\begin{aligned}
& 47 \text { Wild., p. } 147 . \\
& 48 \text { Ibid., p. } 148 .
\end{aligned}
$$


nature, other good things like health of body, physical strength and money are also required for the fullest realization. [Laws $631 \mathrm{~b}-\mathrm{e}$ ] ${ }^{49}$

\section{The Concept Of Forms In Natural Law}

In the previous chapter we explored the definition of the term nature as seen in the dialogues of Plato. Specifically we examined the concept of tendency in the Platonic thought. Before going further there is a need to investigate another element of tendency.

Is there a difference between tendency and teleology? Teleology is defined as the theory of purpose, ends, goals, final causes, values. It explains the past and present in terms of the future. Teleology does not imply a personal consciousness, volition or intended purpose. 50 This is the definition that A. E. Taylor gives it also. ${ }^{51}$ Wild too supports this definition. 52

There is of course an attempt here by both Taylor and Wild to (perhaps) dereligionize the concept of nature. This is due in large part to the threat that Darwinism played in dethroning God (as the Christian church saw it) from an active role, if any, in the world. Teleology had been the rather exclusive domain of Christian philosophy. Men such as Taylor and Wild were attempting to defend Plato and his view of nature, (which after all was very appealing to the Christians to begin with) from what were the avowed enemies of religion and much of Platonic thought. They couldn't do this while hampered by such a dogmatic and narrowly defined view of nature. They needed to show that

49 Ibid., pp. 148-149.

50 Dagobert D. Runes, Dictionary of Philosophy (Totowa, N.J., Littlefield, Adams \& Co., 1976) p. 315.

51 A. E. Taylor, Elements of Metaphysics (London: University Paperbacks, 1961) pp. 55, 309-311. 52 Wild., pp. 74-75. 
Socrates and Plato had come to their views of nature without the intellectually oppressive (as they saw it) weight of an immanent revelation from God.

Plato and others who defended the theory of moral law held that sensory facts immediately presented to us are not perfectly determinate, fixed and complete, but rather that they are indeterminate, dynamic and tendential. [Phaedo 74d-75] They are never simply what they are, but also on the way to something that they now are not. The world is dynamic and in flux. This issue cannot be settled by any appeal to logic or to a priori argument of any kind. It can only be settled by careful attention to experience. If change is really a primary datum, then tendency must be recognized as a basic ontological fact, having nothing to do with projection of subjective purpose or teleology, in the ordinary sense of this word. 53

This is not to say though that there is no purpose to creation. For Taylor at least, on this point Plato is teleological. 54 What both men are trying to again, is to disconnect every action from an assumed conscious, i.e. moment-to-moment design (or Christian teleology). They want to show that the concept of natural law can be arrived at without having it be established on a (continuously) direct revelation from God. And in conjunction with this they reject the idea that any legitimacy of natural law must be based on such a revelation. Wild refers to this as "immanent teleology."

This is an important point. Plato and Socrates did believe that creation was brought into being by God (in a non-denominational sense, if we'll allow it), and that there is a definite purpose and design to this creation. Most importantly, this design/purpose can be discovered by the mind of man. God's structure is apparent according to Plato. So Plato did not deny revelation as such -- it simply did not have a direct place in his philosophy. There wasn't a need. And while we find Socrates in the Apology (28e-31d) speaking of his mission which God has given him, i.e to exhort men to the life of the Good -- it was

\footnotetext{
53 Ibid.

54 Taylor, Plato, p. 492. See the Laws 896e-898d.
} 
not a revelation that he (Socrates) received. The Good is apparent if men use the gift of reason which God has bestowed on them. 55

This issue is of some importance. It has a bearing on the concept of Forms. It also directly effects the idea of natural law as it is found in the sixteenth century and as it has come to us from that time. But as we will see later, it was not the aspect of the "christianizing" of Plato's philosophy that did such damage to the original Platonic structure, it was the development of the philosophy of materialism and the cult of individualism. This will be explained in the chapters dealing with and William of Ockham.

Plato's Realm of Forms. Plato's concept of Forms is central to his structure of natural law. It is also the most difficult of all his ideas to grasp, and has been historically. Volumes have been written on this one particular subject. It is the central point over which Aristotle himself could not come to an understanding and which caused him to reject it and its implications in Platonic philosophy. 56

The concept of Forms is critical to Plato's concept of natural law for several reasons. The first concerns the source of justice. Next how can we as humans know justice (the Form), which is so often defined differently by conflicting individuals and groups.

What does Plato mean by the realm of Forms? First it must be understood that this realm is a wholly non-physical reality. All things partake in Forms but they are not the

55 Ibid., pp. 164-165.

56 A. E. Taylor, Aristotle (New York: Dover Publishing, 1955) pp. 32-33. Also see Taylor, Socrates (New York: Doubleday Publishing, 1948.) pp. 170-171. 
Form itself, nor does the Form reside "in" anything. To fully understand this point it will be necessary to look carefully at a number of dialogues and to various commentaries on them.

In the Phaedo, as well as the Symposium and the Republic the concept of Forms are addressed at length. If we say that a certain object is beautiful what do we mean by that? A.E. Taylor takes his analysis from this point in his discussion of the Phaedo (100c102a).

If we ask why something is beautiful we may be told in one case, "because it has a bright colour," on another "because it has such-and-such a shape." The point that Socrates wants to make is that such answers are insufficient. There must ultimately be one single reason why we can predicate one and the same character, beauty, in all these cases. Having a bright colour cannot be the cause of beauty, since the thing we call beautiful on the strength of its shape may not be coloured at all; having a particular shape cannot be the cause of beauty, since we pronounce things which have not that shape to be beautiful, on the strength of their colour, and so on. Hence Socrates says he rejects all these learned explanations and sticks to the simple one that universally the reason why anything is beautiful is that "beauty" is "present to it," or that it "partakes of" beauty. The thought is that whenever we are justified in asserting the same predicate univocally of a plurality of logical subjects, the predicate in every case names one and the same "character." It is these characters which Socrates calls "forms." We might call them "universals" if we bear two cautions carefully in mind. They are not supposed to be "ideas in our minds" or anything of that sort; they are realities of which we think. Also, as the case of "beauty" is well adapted to show, a "form" may be "present" to a thing in very varying degrees. A thing may be beautiful, or it may be only very imperfectly beautiful, and it may well be that nothing is superlatively and completely beautiful. We should also note the precise character of the relation which Socrates calls "presence" or "participation" or "communication" is nowhere explained, and his hesitation about the name for this relation (100d) may perhaps mean that he feels that there is an unsolved problem involved by his "postulate". 57

In the Symposium 58 we are given another way of viewing participation. Here the seeker of Beauty moves successively from the beauty of individual objects to people to greater beauties such as institutions, then to learning and knowledge and finally to

57 Taylor, Plato p. 202

58 Symposium, 21 la-b. See also Taylor., Plato p. 230. 
Beauty itself. What is important about this particular passage is that it is a strong example of what Socrates means when he speaks of participation. In the discussion he holds with Diotima, a "priestess or prophetess of Mantinea" 59 we see the concept of participation in Form(s) by degree. In other words, something is not beautiful or not-beautiful. Beauty is manifested to varying degrees by all those things that participate in Beauty.

In the Republic we find reference to the supreme Form. It is the Good. 60 In Book VI the concept of the Good and its relationship to both sensibles and other Forms is conveyed to the reader through the analogy of the sun. 61 The sun is the source of all life on earth, and so, likewise, the Good is the ultimate source of all other Forms. For Christian scholars and theologians the question has been, of course, is the Good in the Platonic dialogues the same as God. Both Taylor and John Burnet did not think so, and neither does Patterson. But this is a qualified negative. 62

Whether the Good is accepted as God in the strict Christian sense of the term is not really an issue for natural law. Socrates and Plato both believed in a supreme Being -though (as previously mentioned) there was no consideration of immanent revelation as being necessary in order for Man to participate in the divine creation. The important point here is that there is a source for all other Forms. Forms don't have a static existence; they exist with purpose. There is a rational design at work in nature, which again is tendential. 63

\footnotetext{
59 Taylor., p. 224.

60 Ibid., p. 287.

61 Republic, 507b-509c.

62 Taylor, pp. 288-289.

63 Patterson., p. 124.
} 
How can physical reality participate in Forms? This is the problem that challenged both Socrates and Plato and one which Aristotle could only resolve for himself by denying Plato's explanation and formulating his own. 64 The problem is not completely solved by either of the latter two, at least to the satisfaction of their critics. What Socrates and Plato did leave us with, concerning the issue of participation are a number of powerful myths and analogies. These should assist us in coming to an understanding of a very difficult and abstract subject.

As already mentioned the sun analogy in Book VI of the Republic is one example of how this participation is explained in the dialogues. While the focus in this particular section (Republic 507b-509c) is, as already stated, primarily about the Good and its relationship to the other Forms there are other interpretations that can be successfully assigned to it. It is important to note that Plato, by his own admission as well as that of Aristotle did not reveal all of his thoughts on the realm of Forms in the dialogues. The discussions in the Academy were not written down by Plato, and he urged his disciples to not write and disseminate these teachings, because the majority of people simply wouldn't understand them and there would likely be opposition. 65 So what we have in the dialogues is by no means the final word on the theory of Forms. Indeed, it would seem that Plato's intention is to take his readers to a point where they can successfully continue the intellectual journey on their own. 66

The terms "participation" and "image" in the dialogues both carry strong clues to this problem. The analogy of the sun conveys a good deal of what Forms have in relation

64 Taylor., Aristotle p. 60. See also Taylor., Socrates pp. 170-171; Patterson., p. 130., and Frederick Copleston, S.J., A History of Philosophy Vol. I, (Garden City, New York: Image Books), pp. 202-203.

65 Giovanni Reale, A History of Ancient Philosophy: II. Plato and Aristotle (Albany, N.Y., State University of New York Press, 1990), pp. 10-18. See also, Taylor., Plato pp. 286, 503.

${ }^{66}$ Reale., p. 19. 
with the sensibles of the physical world. The sun provides light to the eyes thereby aiding the eye to see everything around it. Even though the eyes have the capacity to "see", without light they would be unable to function. The sun is not vision itself. Nor does the sunlight "become" the objects beheld by the eye. But the light from the sun makes it possible for us to know that the object before us is, for example, a square block of marble.

The same can be said for the Good in Platonic theory. It is the source of all other Forms. By its aid we know these other Forms (Republic, 508d-e). Their image is conveyed to our reason by the spiritual illumination of the Good.

Yet beyond this "imaging" analogy there is also the idea of participation. This is more firmly made clear in the Phaedo (75). No image could be conveyed to our minds if we did not see this square block of marble (for instance), recognize what the object is and what Form it currently takes. We know the squareness, we know it is marble, we are in the act of knowing, we are participating in the Forms by receiving the information conveyed and coming to an understanding of what we are seeing. 67

The physics of what the physical world is, in relation to the world of intelligible Forms, is not the point of this paper. But in order to further clarify Plato's view of participation we need to give it further examination. In this world we know of an objects qualities. We can't really know its essence as quantum physics has discovered in the past half century or so. Generally our knowledge of an object comes by way of comparison to its opposite. We know it is dark by the absence of light. We know that it is cold by the

${ }^{67}$ Patterson., p. 161 - see notes \#12,13, 14. 
absence of heat. 68 We sense when it is becoming less cold, less dark. In this world everything is in the process of coming-to-be. All things come into existence, exist for a certain period of time in a certain space, and then cease to exist. If we extend this example, if we state that a situation has become worse then we acknowledge that at one time it was better then at present. Further if we state that someone has acted unjustly we recognize a standard of justice which is currently not being upheld.

This can be seen in the Cave analogy of Book VII of the Republic. ${ }^{69}$ Among the other lessons found here we find again the idea of greater participation in the Forms. As our fellow is freed from his bonds, and begins to explore the cave and the cause of the images on the wall, and then further, as he proceeds (painfully) from the cave into the greater world he is led to recognize not a reality/unreality dichotomy but rather a coming-to-Reality (via degrees of perception) concept. When the fellow is sitting on a hill of beautiful grass with the warm sun shining on his face (along with all the other attendant sensations) the world of the cave must, in comparison, seem very much like an unreality to him. But he comes to understand the cave is only unreal in comparison to this greater perception he has now gained. He moved from the "less real" condition in the cave to a "more real" condition in the outside world. But he did not reach an end-state i.e. a completion or total encompassing of Reality, This is important to note.

This physical world then for Socrates and Plato is not an illusion. It is real in and of itself. But it is only one element of reality-as-a-whole. This is evident to Socrates by the very instability of this world. Everything in it is in the process of coming-to-be or ceasing-to-be. Yet all these perishable things that come into existence continually reflect

\footnotetext{
${ }^{68}$ See the Phaedo, 71., pp. 53-54.

${ }^{69}$ Republic, 514-517.
} 
the same Form(s). 70 If there is instability, i.e. the composition and decomposition of physical entities, then there must be stability. The reality of the Forms continues even though the individual objects that participate in them come and go. Things are more or less faithful reflections of the Forms. Returning to the sun analogy we can again view this from another angle. The sun shines on all things alike. Each thing reflects this light and we see it, as already stated. But even though the sun shines on all alike, and all things reflect this light, there are variations in the degree of reflection. A rock will reflect light to a certain degree, but in comparison to a perfectly clean mirror one could almost state that the rock does not reflect sunlight. This is a fundamental element of the Platonic concept of participation. Indeed, the mirror so faithfully reproduces the heat and light of the sun that one could point to the mirror and say, (with an obviously important qualification) this is the sun.

In the Timaeus the term "receptacle" is used to further refine the concept of participation of Forms. The receptacle is not of this world, but rather the means by which the Forms are conveyed to this world. The analogy of the film screen might help here. The screen is like the physical world. The moving images that play across the screen are not created by the screen, nor are they given their distinguishing characteristics by it, nor does the screen influence the sequence of events. It is an extremely passive entity. But without the screen the "playing out" of the story could not take place. The screen is real, Plato would tell us, but what conveys meaning to us? The screen itself or the images (Forms) that move across it? 71 To carry this analogy further we must view the projector as the Form itself. The light streaming from the projector carries with it the Form also --

${ }^{70}$ There is no need to go into the whole issue of a sensible participating in a "bundle of Forms." Patterson's book goes into this in great detail.

${ }^{71}$ F. Cornford, Plato's Cosmology (Indianapolis: The Bobbs-Merrill Co., 1937) p. 181. See also Patterson., pp. 84-86. 
it is the receptacle. It is what conveys the Form to the screen. Again, it is not a part of the screen itself, but until it reaches the screen it is unintelligible to us (in this world). Another way of viewing this would be to consider the sun analogy. The light of the sun reaches the mirror via the rays streaming out from the sun -- the sun itself doesn't send out little chunks of sun matter which find their way to earth. It is important to note then that the term receptacle used by Plato must not be thought of in terms of a physical container of some sort.

Forms and Artificial Objects. Another matter which tends to cause a good deal of confusion with regard to Forms and participation are the examples given in the dialogues of artificial objects, beds, shuttles (a cloth weaving device) tables, etc. For centuries commentators, both for and against Plato, have either tried to explain this away, or used it to point out the impossibility of the realm of Forms. If there is a Form for every physical entity, then the realm of Forms must be terribly crowded, indeed a near exact copy of this world (taking into account variations in entities, which means Forms for those variations also). But this is ludicrous. How did such a misconception come to be?

There are several plausible answers. First and foremost the mistake seems to be in the near exclusive focus on physical objects and the material world as being the foremost in importance. Over and over we see in the Platonic dialogues references that the material world is of limited value to the human soul. It should be noted also that many of the commentators through the centuries who have made this error were existing in a Man-to-Object axiology, so it is only natural that such an intense material focus should occur. Also at various times there was no direct access by European scholars to Plato's writings. Even so Aristotle himself states in the Metaphysics (A. 991b6, M. 1080a6) that 
in the Academy it was clearly understood that there were no Forms for artificial things such as a house or a ring. 72

A. E. Taylor is somewhat ambivalent on this point. He points out that examples of these artificial things are given in the dialogues but also stresses that Aristotle was perhaps inferring a difference of what was taught by Socrates (and recorded faithfully by Plato in the earlier dialogues) and that which was taught by Plato both in the Academy and also in the later dialogues. Taylor suggests that even as early as the Republic Plato seems to have been refining Socrates' concept of Forms. 73 Again it needs to be pointed out that Plato was well aware of the issue of whether there was Forms for every entity. In the Parmenides young Socrates is being bludgeoned by the older Paramenides' word-logic. When confronted about whether there are Forms for such things as mud, hair, etc., Socrates states that he is not sure about that -- but he feels quite certain that there are Forms for such things a Justice, Truth, Beauty, Equality, etc. 74 This dialogue is very complex and quite subtle. Plato uses the very logic of both Paramenides and Zeno to rip apart the objections used by the latter two against Socrates. But what is important here is to note that Socrates once again reaffirms that, of the existence of the positive attributes (Forms), he has little doubt.

72 There has always been a good deal of speculation over this point. My personal understanding of this matter is that Plato, when stating that there are Forms for everything is not saying that there is literally a mirror image of e.g. a pencil in the realm of Forms. Rather he means that the attributes of the pencil are to be found there. The pencil itself is a physical manifestation of those qualities. Another way of thinking of this is that Jesus Christ was asked if John the Baptist was the return of Elijah. Jesus said that he was, John said that he was not. Both were correct. John was not the literal physical return of the man Elijah. But Christ seems to have been referring to the qualities that Elijah exhibited, c.f. Luke 1:17. JMH

73 Taylor, Plato pp. 286-287. See also: Socrates p. 170.

74 Parmenides 130c-131, pp. 924-925. See also Taylor., Plato, pp. 353-354. 
This discussion on whether there is a Form for all things, or only a restricted number of entities has continued right down to the present day. While there has been a great deal of insight given to this issue - and a few brilliant ones - it seems that there are other avenues to this question which have not been explored fully in the West. This is important to the main point of this paper - the development of natural law during the Renaissance.

Forms and Natural Law. If we bring Plato's definition of nature together with the concept of Forms and, specifically, if we concentrate on the main issue of the Forms, i.e. the positive attributes (justice, beauty, equality, etc.) we will come to a more complete view of natural law, as conceived by him.

From both Plato's definition of nature (and consequently natural law) and his concept of Forms we can see that Justice, (i.e. natural law) is not a static thing. Nature is tendential. Forms require, by their very existence, participation, which is also tendential. Consequently natural law, as it exists and in its application is a thing that flows. Justice is not in anything. Humans, and to a much lesser degree, institutions (such as a constitution and the government formed around it) participate in this Form, and so Justice (as well as any Form) is much like a river or sea -- its course and movement are dictated by the shape of the earth beneath it. By this I mean that just as water takes on the shape of the receptacle that it is poured into, the manifestation of a Form is determined to some extent by the physical object. 75

75 We are able for instance to determine whether something is somewhat round or a true circle. The object that comes closest to being a true circle manifests more completely the Form that we know as a circle. JMH 
Plato's Forms and the State: A Preview. So far we have reviewed Plato's definition of the term nature and attempted to understand the concept of Forms as developed by both Plato and Socrates. While there are numerous elements that are important to the Platonic idea of a just society we need to briefly mention one other element that is fundamental.

For Plato Justice can only be manifested by humans, not by or through a constitution. 76 For Plato if the State is corrupt it is due to the corruption of the individual. The state is a sub-entity. There is no justice in a State because the State is simply an identifiable group of individual human beings. Without the group's existence there is no State. In Plato's concept of society the individual has the duty to manifest justice, in various forms, in society. The whole purpose of the Republic was to discover the true nature of justice manifested in the individual by studying something more tangible -- the State. 77

Justice in the individual is not a happenstance. The dialogues clearly show that justice, like all other Forms (attributes when displayed by a conscious, rational entity) can only be discovered and brought to greater clarity through education. 78 Justice is, for Plato, one of the greatest Forms, it is a moral element of the soul (if the soul so chooses to manifest it), i.e. it is a "natural" element of the soul's tendential nature. Law is not synonymous with justice. Law can stem from justice, the latter existing in and being manifested by the human soul. ${ }^{79}$ Law is simply a material manifestation of justice, or can be. Consequently, a law can be more or less just. Laws are developed by human

\footnotetext{
${ }^{76}$ Barker, Greek Political Theory pp. 284-285.

77 Ibid.

78 Taylor, Plato pp. 261-262. See also Wild., p. 26. For the capacity to know Forms see the Phaedrus 247e $250 \mathrm{a}$. That these virtues can be taught see, for instance, the Protagorus $361 \mathrm{a} 7 \mathrm{-c7}$.

${ }^{79}$ Barker, p. 186, 177 (note \#2).
} 
beings. If the people who write down laws are struggling to manifest Justice in the Platonic sense, the laws will reflect this. But the laws themselves are static images of the Form. This is why Plato put little trust in the idea of a constitution as the focus of justice. It could not be, because justice springs from the human soul. Humans can create greater and more just laws -- and they can stretch the "original intent" of the law. This attempt to stretch is in itself an admission of Plato's point -- humans are the source for justice as they participate in it. When a judge attempts to stretch the original law Plato would view this quite possibly as an attempt to reshape a static image of the Form justice to fit our now greater vision of what justice is. ${ }^{80}$ Again this is why Plato was ill-at-ease with any attempt to write down "ultimate truths." They could not be contained in the written word and the reader may very likely assume, erroneously, that this document now contained the truth. Forms, being, at least in relation to humans infinite, cannot be contained but only manifested to greater degrees of perfection. ${ }^{81}$

This is why Plato stressed the duty of the person to the state, and not the state to the person. The justice of the state is only as manifest as it is in the individuals that compose that State. This thought is now a very odd one to a modern democratic mind. It smacks of fascism. Plato has been accused in the past fifty years of being just that. We will explore this point further in the last chapter.

Viewed from perhaps a bit more metaphysical angle Plato would also argue against an over-reliance on the constitution because it is a limited and mutable manifestation of the Form justice. ${ }^{82}$ If this over-reliance occurs, the natural tendency of the soul, which

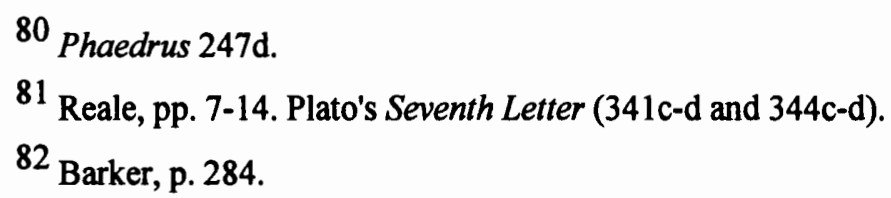


is to strive to perfect itself through acquiring a greater degree of human virtues, becomes thwarted or distorted. The ability of the human individual to know justice decreases through a lack of exercise. To have one or several individuals impaired is difficult, but to have a society where even a significant minority of the population allows this to happen would be, in Plato's mind, devastating to the health of the state. The citizen must see to the health of the state. They "give" to the state and in turn the state "gives" to them. But the primary responsibility falls on the individual first, it is their actions toward the state that creates a just society. The similarities, of course, to the functioning of a healthy body are impossible to ignore, and Socrates does use this metaphor. Any disease of the body can be potentially lethal, if allowed to continue unchecked. A cancer is a group of cells that refuses (due to mutation from its original nature) to contribute properly to the tendential nature of the collective body, and it will eventually destroy that body if this distorted tendency continues.

The primary protection for the state then is the proper education of each of its constituents. Each citizen is assisted to discover within themselves what their capacities and abilities are, so that they can be fulfilled in their nature, and consequently they can contribute properly and positively to the nature of the state. A citizen who is forced into a position they are not suited for would only be susceptible to becoming cancerous. Their nature would be distorted, and this in turn would effect all those around them, to some degree, and it would spread. Justice, in this sense then, is balance, "giving each man his due." Law is only one vehicle for the application of justice. Humans are the primary source. They can administer justice as necessary. Education is the seeking out of what is just for each individual, helping them discover that unique element within their nature 
that makes them an individual. When this is done successfully, then the natural tendency is for that citizen to tend toward contributing to the state meaningfully. ${ }^{83}$

\section{CONCLUSION}

What has been attempted here in this first section is to show that the true origins of the concept of natural law in the West began with Plato. The "Platonic system" (a term that is not without its controversy) was the most comprehensive philosophy developed to deal with the issue of a healthy, thriving society. Plato first dealt with the issue of what we refer to as metaphysics, or the more technical term ontology, (being from being). The question is "why" as well as "how" and "what". How do we know this is beautiful or right or just. What is justice, beauty, etc. The continual emphasis by both Socrates and Plato was that knowledge or more accurately the ability to know cannot come only from the physical world. 84 The Platonic concept of Forms, first suggested by Socrates and later greatly expanded upon by Plato, was a radical departure from all previous theories. Beyond this it was revolutionary on a number of levels. On the individual level it made each human primarily responsible for their mental and spiritual development and consequently their response to society at large. On the collective level, and aimed primarily at the governance of this society, it strongly suggested that it was indeed possible to have a just society through outlining how such a society might possibly look and operate, and what's more, that Justice could be delivered through the mechanism of the body of governors. But justice cannot be found on the physical plane of existence. It might be imperfectly embodied in a constitution or set of laws, but humans are the

\footnotetext{
83 Wild, p. 155.
}

84 A book that has been helpful in respect to this statement is Rosemary Desjardins, The Rational Enterprise: Logos in Plato's Theaetetus (State University of New York Press, Albany, N.Y., 1990). 
manifestors of justice. And this cannot occur on a sufficient level unless the education process were radically restructured. Education allowed all people, at whatever level of capacity they may have on a mental/spiritual level to access these Forms and manifest them. Without such a reform the rather abrupt philosophy of Thrasymachus found in the opening chapter of the Republic and echoed repeatedly throughout the centuries would be smacks of fascism. Plato has been accused in the past fifty years of being just that. We will explore this point further in the last chapter. 


\section{CHAPTER III}

\section{FOLLOWING THE COURSE OF NATURAL LAW}

The concern as stated in the introduction is to discover the changes that occurred from Plato's conception of natural law to the period of Suarez and Vitoria at the time of the Spanish Renaissance during the sixteenth century.

Between the death of Plato and the birth of Francisco De Vitoria over eighteen centuries passed. Plato's natural law had undergone significant changes to such a point that by Vitoria's time Plato's concepts were nearly an empty shell, a useful footnote to authors wishing to support their particular narrow views or to give lip service to the reemerging term "natural law". Of course it is impossible to cover 1,800 years in this section. But what can be done is to show the major turning points and suggest what was critical about each one.

The first distortion in the Platonic system started with Aristotle. The key element upon which all subsequent changes occurred, at least until the Renaissance, was Aristotle's version of the concept of Forms. Aristotle was not able or willing to accept Plato's Realm of Forms. This is not to say that he denied the existence of the supersensible in toto -- he simply couldn't accept Plato's version of it. 85

${ }^{85}$ Reale, p. 254. 
As already stated Socrates and even more importantly Plato recognized some of the problems caused by their insistence that there was no Form in a physical object. ${ }^{86}$ All the objections raised against the realm of Forms, found both in the dialogues and subsequently in Aristotle, are based on the belief that the physical world is, in some way, the fundamental realm of existence. Also, as can be seen in the Parmenides the strongest argument against the Platonic Forms is the idea of the "two worlds", Parmenides' insistence that there could be no relation between the ideal world of Forms and this world. ${ }^{87}$ In this dialogue while the existence of the realm of Forms is not disputed it is argued that it certainly is not a superior realm. The main thrust of Parmenides objection is how can we believe that entities in this world somehow participate in something from a non-physical dimension. As Taylor points out, this dialogue, one of the most controversial of all Plato's works, demonstrates that he was well aware of the more powerful arguments against the realm of Forms. ${ }^{88}$ But as far as both Socrates and Plato were concerned the puzzling questions brought up by such a theory were nothing in comparison to the immense problems that would occur without such a theory. ${ }^{89}$

Aristotle, who it should be pointed out, spent very little time with Plato, due to the latter's travels, not to mention being thirty years his senior, felt he had an answer to this problem. The answer would have a tremendous effect on various branches of human knowledge, including the areas of law and politics. Aristotle's answer (keeping the Parmenides in mind) was that the Form of man, for instance, was inherent in the substance of man. It is important to note that Aristotle did not mean by the term

\footnotetext{
${ }^{86}$ Timaeus 51e-52a.

87 Parmenides 133a-135c. Also see Taylor, Plato p. 358.

88 Taylor, p. 170.

${ }^{89}$ Ibid., p. 359.
} 
"substance" crude physical matter, but some element superimposed on the physical matter. The Form in this condition is the physical entity's essential character, it's template so to speak. For Aristotle Forms in a realm separate (and here his definition of separate is critical to the whole argument) made no sense. Aristotle must have understood Plato's references to a separate realm of Forms in a materialistic fashion, i.e. literally cut off and having no connection with the other. 90 Although Giovanni Reale and a number of other scholars have in the past thirty years or so attempted to minimize the differences between Plato and Aristotle there is no way around this rift. Despite Reale's statement that Aristotle did not want to deny the existence of the Forms, but simply the nature that Plato had assigned to them 91 the critical point is that two diametrically opposed World-views were formulated by these two men. Both lead to radically different conclusions about the very nature of our existence. The very first distortions then, in the Socratic/Platonic theory of Forms occurred with the man normally touted as Plato's greatest student.

\section{Platonic Philosophy and Islam}

Fifteen centuries separated the death of Aristotle and the birth of Thomas Aquinas. Aristotle, and to a far greater degree Plato, had been lost to most of Europe for nearly two-thirds of that time. And it was in these fifteen hundred years that another significant distortion occurred.

It started with the closing of the Platonic Academy at Athens in A.D. 529 by Justinian. The majority of Neo-platonic philosophers fled to the Persian court of Kisra

\footnotetext{
90 Copleston, Vol. I., p. 292-293.

91 Reale, p. 254.
} 
Anushirwan. 92 Eventually the writings of many Greek thinkers found their way into the hands of various Islamic philosophers. But from the period of when these writings were introduced to the Persians until they reached the Islamic philosophers another four centuries passed. And if we simply focus on the two greatest Muslim philosophers (in terms of their influence on European thought), Ibn Sina and Ibn Rushd (or as they came to be known throughout Europe Avicenna and Averroes), they were removed from the time of original introduction by five and six centuries, respectively.

This is important because at some time before Ibn Sina and Ibn Rushd began their studies of Greek thought something very critical occurred. A sizable portion of Plato's actual dialogues were no longer available, although there were a number of synopses. Also Plotinus, possibly the greatest Neo-platonic philosopher ever (A.D. 204-5 -270) had his writings and commentaries mistaken for either Aristotle's own or that of a Aristotelian commentator. In the end Aristotle became the primary focus for the two greatest Arabic influences on European thought.

Virtually all that Thomas Aquinas knew of Platonic thought then came through the biased filter of Aristotle's writings. And the minuscule number of Platonic dialogues that did exist in Europe at this time were little read -- owing in part to the extremely poor translation. It must be remembered that from Augustine's period until the fifteenth century virtually no one in Europe could read Greek -- indeed Augustine himself did not know it and had to rely on Latin translations of Plato's works.

92 Eugene A. Myers, Arabic Thought and the Western World (New York; Frederick Ungar Publishing Co., 1964., p. 8.) 
For Europe then Thomas Aquinas became the primary conduit through which Aristotle re-emerged as a significant philosophical force on the intellectual landscape. And while we need to note that Aquinas certainly did not accept uncritically all of Aristotle's philosophy, he did accept and continue the Aristotelian version of the concept of Forms.

In regard to this it is important to also note that Aquinas primarily used the terms species, genus, and universal. Both of these are essentially Aristotelian as defined and used by Aquinas. When disagreeing with Plato he specifically uses Plato's term, "Form". 93 The terms "universal" and "species" have, along with "genus" connotations that are far more narrow in scope than Plato's "Form" or "idea." They stemmed from Aristotle's empirical training. So, even though universal is for Aristotle equivalent to Plato's Form, it is far more closely linked to the physically defining terms species and genus. For Aquinas then, just as for Aristotle universal was not actually separate from the physical entity. What's more, it never was. There was never a point where the universal/form had a separate ontological existence outside whatever physical entity it was present to. In other words the physical universe is the ultimate existence, there is no significant, and certainly no superior reality beyond it. Form then is not pre-existent of and superior to the physical entities that manifests them. ${ }^{94}$ The difficulty that this line of thought causes for natural law becomes readily apparent when a near contemporary of Thomas Aquinas, William of Ockham turns his gift of logic on Aristotle's Universals.

93 Anton C. Pegis, Introduction to St. Thomas Aquinas (New York, N.Y., Modern Library, 1948)., p. 378, cf. pp. 402-3, (ST Q. 84, art. 1, cf. Q. 85 art. 1.

94 Copleston, V. II., pp. 326-7. 


\section{Natural Law at the Dawn of the Renaissance}

William of Ockham (1290?-1349) was probably born at Ockham in the county of Surrey near London. He was an ordained Franciscan. He pursued theology at Oxford from approximately $1309-15$. Ockham is a very difficult figure to deal with, historically, philosophically, and politically. Arthur McGrade begins his study of Ockham's "political" writings with this observation:

There seems to be no way round Ockham. Sooner or later he confronts every worker in late medieval history.' Unfortunately Ockham seems not only unavoidable but also enigmatic. He has been seen as the destroyer of the high scholastic synthesis of faith and reason, yet his personal orthodoxy has seldom been questioned in recent times, and the avowed target of his critical attacks was the 'common opinion of the moderns' rather traditional theological systems. He was involved in a literary war with the popes at Avignon that rivaled in length and bitterness any previous contest between empire and papacy, yet he has also been described as 'a constitutional liberal. . not an anti-papal zealot'. If we restrict our attention to the content of Ockham's political writings and consider his life, his speculative thought and the world around him only as they clarify the inner structure and meaning of these works, difficulties still remain in even outlining our subject, let alone providing a finished account. Indeed, it has proved so hard to mark off the politically significant elements in Ockham's gigantic body of writings that some scholars have doubted he was a political thinker at all. 95

For the moment what is critical is Ockham's views on universals. For him a universal was a designation, a name and nothing more. 96 Ockham reduces the ill-conceived

\footnotetext{
95 Arthur S. McGrade, The Political Thought of William of Ockham (Cambridge: Cambridge University Press, 1974) p. 1.

${ }^{96}$ Meyride H. Carré, Realists and Nominalists (London: Oxford University Press, 1946). p. 113.
} 
Aristotelian compromise on Platonic Forms to a materialist's logical conclusion. Since Aristotle imbedded Form in the object (and despite his quasi-Platonic back-pedaling with various terms, that is exactly what he did) he actually opened the door for Ockham's reduction of universals to mere names (mental notation status) and nothing more. 97 Ockham's argument against universals (as they were presented by other philosophers at the time, and despite Russell's contention, as they are meant to be understood by Aristotle himself, is logical. Aristotle insisted that Forms are imbedded in the entity, yet at the same time are, in some way distinct from the entity itself. Ockham's attack on this is obvious. How can a universal, e.g. Man, be both universal and individuated at the same time in the physical universe? How can it be, in other words, many and one simultaneously?

Echoing a criticism which we have heard leveled by Abaelard against William of Champeaux, Ockham protests that there is no single identical and simple entity which is present in each of a number of particular things at the same moment. On this view the particular thing and the universal are two distinct existences; and a single thing cannot exist in several other things. But some philosophers offered another interpretation of the universal. They maintained that the universal was capable of being communicated to many things at the same time. What is the nature of this communication? If it means that the universal is imparted to many things at once without causing an alteration in itself or multiplying itself in the things it remains a single identity or an individual; and our former difficulty returns. Most of Ockham's criticisms against universals are variations on the theme that a single distinct entity appearing in a multiplicity of individual things is a contradiction in terms. For the universal is described in language proper to the individual. But if it is an individual it is incomprehensible how it can appear in a multitude of individuals. If it is present in a number of particulars it cannot be a single entity. He roundly concludes that there is no such being as a universal in the sense of an entity present in each of a number of items of experiences and common to them. ${ }^{98}$

97 Bertrand Russell, A History of Western Philosophy (New York, N.Y., Simon and Schuster, 1972). pp. 472-3. Russell, a fine materialist philosopher in his own right, tries here to explain Ockham's legitimate (as he sees it) complaint with the issue of Universals. It is, according to Russell a simple matter of men such as Duns Scotus, and to a much lesser degree Aquinas, making the mistake of mixing logic with metaphysic.

98

Carré, pp. 108-9. 
Carré goes on to state that Ockham rejects all modes of realism. 99 He clearly attacks abstract thought, and in its place establishes notitia intuitiva, intuition. Abstract knowledge quite often leads to confusion, according to Ockham, because the mind fails to distinguish accurately between items of experience. Direct perception is the ultimate way to discern reality. 100

The second blow William of Ockham brought to bear on the ancient concept of natural law was on the subject of law itself. Natural law was, for Ockham grounded in God's will. At first glance there seems to be little distance between this assertion and what we find Plato stating in the Laws. Actually, though, there is a significant difference. Ockham's conception of natural law is positivistic. For Ockham, God is the ultimate Lawgiver. He has set natural law in motion, and $\mathrm{He}$ can dispense with it or deviate from it if He so wishes. Yet at the same time natural law is absolute, immutable, and admitting of no dispensation. 101 But natural law does not possess an intrinsic rationality or any ontological foundation; it is wholly dependent at all times on the Divine will. And even though right reason exists and leads us to morality, it is due to the positive influence, again, of God's will. For Ockham God was in no need of, as he saw it, the intermediaries of the Forms. Justice was dispensed by God directly, and revealed in the Bible. Indeed, since, in Ockham's eyes there were no Forms, and abstract thought could only lead, more often than not to confusion, the only way humans could know justice would be through God's direct revelation. Explicit statements and examples from the Bible could be used to guide people in applying justice. Essentially this is biblical-legal positivism.

${ }^{99}$ Ibid.

100 Philotheus Boehner, ed. \& trans., Ockham: Philosophical Writings, (Edinburgh: Nelson 1959) pp. $32-$ 37. This section from Ockham's own writings is quite relevant to the point above. Also see pp. xxviixxviii.

101 Francis Oakley, Natural Law, Conciliarism and Consent in the Middle Ages, (London: Variorum Reprints, 1984)., Ch.XV pp. 69-71. 
Of course by these standards humans could not be trusted to interpret what they found in the Bible either -- which would poise a significant difficulty in attempting to apply biblical guidelines to the rather fluid societal changes of everyday life. Elsewhere in his writings Ockham seems to realize this and gives grudging respect for limited use of human reason in such areas. Indeed he himself becomes a bold interpreter and extrapolater of the Bible in his attacks against the Avignon Pope John XXII. These attacks initially started with Ockham attempting to defend the Franciscan vows of apostolic poverty. 102 For his troubles he was excommunicated. He then, in exchange for protection, agreed to write in defense of the German Emperor Louis the Barbarian. This arrangement worked nicely until the latter's death in 1347 . Ockham's position then became helpless, and seeking pardon from Rome, he renounced his political ideals. 103

William of Ockham was not necessarily the first to suggest any of these points that have been brought up here. In his attack on Platomie Forms in the guise of universals he was preceded by nearly a century and a half. 104 But he lived at a critical time in the intellectual development of Europe, and he brought to the issue his powerful intellect. His command of the logic of that time was superb. His phiosophy was in many respects the beginning of what came to be termed the via moderna, i.e. modern life. The effect of this philosophy on natural law (as understood in the mode of via antiqua), epistemology, and political science (as we now term it), not to mention theology, can be witnessed to this day. For the purposes of this paper we can enumerate these effects as follows: a) Ockham effectively eliminated the concept of Forms from being seriously considered as anontological foundation of Reality, b) at the same time he seriously damaged any

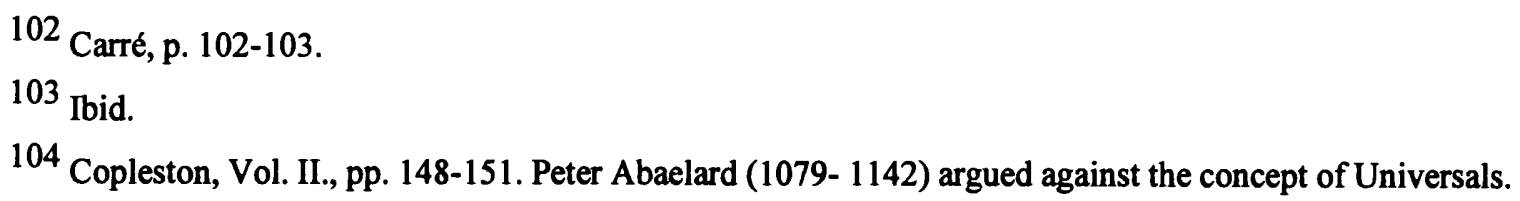


metaphysical avenues leading to the question of epistemology. All knowledge comes by way of the physical senses. Knowledge is derived from empirical study of the material world, c) natural law, or more to the point our understanding of it does not, stem from human reason granted to us by God. That was, at the very least, severely crippled at the time of Adam. It is arrogant presumption for us to assume we can discern any significant portion of God's will as manifested in existence. What we can know of natural law is known through direct revelation, i.e. the Bible. God has no need of such intermediaries as the Form of justice. He is present to us as an immediate presence in our lives.

The philosophy of nominalism which Ockham set in motion stood in direct opposition to Thomas Aquinas and what came to be know as Scholasticism. Nominalism won out in its ability to effect so many areas of human knowledge and social movements. Indeed, the very forces that the Spanish Thomists struggled so valiantly to disprove were all shaped directly and indirectly by nominalism. And as much as the Thomists wished not to admit it, they too were forced to lean, to some degree, on various elements of nominalism themselves.

\section{Natural Law in the Renaissance}

Approximately one hundred and fifty years separated the death of William of Ockham and the birth of Francisco De Vitoria. Eighteen centuries separated Vitoria from Plato and Aristotle. The two philosophical universes, via antiqua and via moderna were mixing and swirling like two mighty rivers, both attempting to control the flow and direction of the new river being created. This period of flux in history is often referred to as the Renaissance. 
It should be noted with some interest that the Renaissance as we have come to know it seemed to pass by Spain. "Spain was almost untouched by the Protestant Reformation or by the Renaissance in its Italian form; she had no scientific revolution to speak of, no equivalent to Hobbes or Locke, no rise of political individualism, no social-contract theory, no industrial revolution." 105

Perhaps because of these factors, as well as others, Spain was host to the last great attempt to keep alive the via antiqua. This revival of sixteenth-century Thomism did not actually begin in Spain though but it reached the full zenith of its rather meteoric rise there. 106 Spain, perhaps because it was frozen in time, so to speak, from the vantage point of the rest of turbulent Europe, lent itself well to the resurgence of (primarily) a medieval philosophical force. 107

There were a good number of significant Thomists during the sixteenth and early seventeenth centuries, not all of them Spanish. But the four which we wish to concentrate on are all of the Iberian peninsula. They are: Francisco Vitoria, (1480-1546); Domingo De Soto, (1495-1560); Luis De Molina, (1535-1600); and finally Francisco Suarez, (1548-1617). Both Vitoria and De Soto were of the Dominican Order, while Molina and

105 Bernice Hamilton, Political Thought in Sixteenth-Century Spain (Oxford: The Clarendon Press, 1963)., p. 3.

106 Quentin Skinner, The Foundations of Modern Political Thought: Vol. II. (Cambridge: Cambridge University Press, 1978). p. 135. It should be noted that one of John Mair's pupils was Pierre Crockaert (c. 1450-1514). He studied at the College De Montaigu, part of the University of Paris. He had come there to study the via moderna, taught by Mair, a leading exponent of Nominalism. After some time he rejected it and began to study the via antiqua, which at that time was having something of a comeback in Paris.

${ }^{107}$ Hamilton., p. 4. 
Suarez were of the Jesuit. ${ }^{108}$ These men represented the most coherent attempt to thwart the onrush of not only the Reformation, but of the philosophy of materialism that attended it. They certainly were not the only ones to recognize the dangers of the oncoming via moderna. The Neo-platonists, or Occult Neo-platonists as they are sometimes referred to, also saw the implications of via antiqua being exiled from the European psyche. 109 Among this group can be counted William Shakespeare. Among his last twenty plays, as well as the epic poems of The Rape of Lucrece and Venus and Adonis there seems to be (if we accept the contention of Mr. Hughes) an underlying theme, the idea that a terrible thing was occurring throughout Europe. Not only was Europe being torn apart by religious strife, but the rise of empirical science supported by the growing philosophy of materialism was just as great a threat in the eyes of men such as Shakespeare, John Dee and Bruno. 110 We will return to this element of the Renaissance later. In the next chapter we will briefly survey the three most potent forces standing against the via antiqua from the perspective of the Spanish Thomists, and see how the Thomists attempted to answer their threat.

The Enemies of Natural Law

Europe during the sixteenth century found itself at a confluence unlike anything it had seen since the time of Constantine's baptism on his death-bed and all that ensued

\footnotetext{
108 While the aspect of the two Orders to which the four Thomists belonged certainly had an effect on the particulars of each of their arguments against their various enemies, the differences are not that significant. All their arguments follow essentially the same lines of thought. I have chosen not to focus any more attention than necessary on the biographical information of these four, but rather concentrate on their philosophical challenges.

109 Ted Hughes, Shakespeare and the Goddess of Complete Being (New York: Farrar Straus Giroux, 1992)., pp. 30-34.

110 Ibid. pp. 20-23.
} 
from that action in A.D. 337. Never before had such a monumental change in the macrocosmic view of an entire civilization, covering such a vast area taken place. Now, some thirteen hundred years later it was again occurring. And while there were certainly old power structures that saw the emergence of Christianity as a fundamental threat to ancient traditions there is actually little room for comparison between the two periods, other than the disruptive power that was released because of these changes.

What was taking place in the sixteenth century was not the replacement of a number of polytheistic religions tied to ancient rites of fertility. Nor was it a decaying empire desperately looking for some form of internal cohesion. But what was occurring was just as earth-shaking, perhaps more so.

The rebellion against the Catholic church had been growing long before Martin Luther arrived on the scene. Indeed, if we look closely at the Church we can find few periods of peace where it was not being challenged. Constantine himself was not baptized in the newly accepted Nician theology. He was, on his death-bed, a professed believer in Arianism, as was his son after him. 111 But there had been no successful challenge to Catholicism since the end of Arianism among the Germanic tribes toward the end of the sixth century. 112

That is until the mid-thirteenth century, starting with William of Ockham and continuing with even more blatant attempts at reform by John Wyclif, (1328-1384) and John Huss, (1373-1415). The latter was burned at the stake by a Church that was, to say

\footnotetext{
111 Rowan Williams, Arius: Heresy and Tradition (London: Darton, Longman and Todd, 1987.) Also see: W.H.C. Frend, The Rise of Christianity, (Philadelphia: Fortress Press, 1985.).

112 Williston Walker, A History of the Christian Church (New York: Charles Scribner's Sons, 1970.) pp. 120-123.
} 
the least, not open to his suggestions. All these men proceeded Martin Luther by approximately a century. All were attempting, not to destroy the Church but to reform it. Neither were they attempting to form a separate church. But what was occurring with their attempts at reform was perhaps even more significant. They were laying the ground-work for not only an open attack on the structure of the Church, but were also leaving the door wide open for an attack on what appeared to be many of the intellectual support-beams that held that structure in place. The reasons for the attacks later on, during the sixteenth century were varied. Certainly the complaints against the policies of the Church, indulgences, etc., were legitimate. Also the feeling that the Church was at one and the same time both meddling in and yet out of touch with the affairs of men caused anger and frustration throughout Europe. Consequently anything used by the Church in its defense, whether explicitly or implicitly, became increasingly suspect. Men who, for instance, were already ambivalent toward the Church found its behavior toward the emerging physical sciences, especially astronomy, to be another clue that all was not right in Rome.

The ability of the Church to hold the social fabric together was degenerating rapidly when Martin Luther appeared. With his successful attack on the Church a Pandora's box was opened that brought back a number of ancient social plagues as well as some new variations. This is how the Thomists viewed not only the Reformation but also the rise of Humanism and for lack of a better term Machiavellianism. The latter two did not find much support from or even worth in the Reformation, but it certainly did provide an open front from which to attack not only the Church social structure but many of the intellectual supports upon which this structure rested. 
What we are interested in here is not the standard issues that, for instance, Martin Luther had with the Church. Rather we want to analyze his newly erected intellectual supports, discover the source material of them, what was new and what was old. From here we will explore what re-enforcement the humanists and Machiavellians added to the general attack on the existing social structure. Please note that by social structure I mean the mesocosm or social universe, of the Europeans. While it is not any more possible to divorce the mesocosm from the axiological foundation of a race than it is to completely study the structure of a house without taking into account the foundation upon which it rests, we need only keep in mind that the European axiology is Man/Object. 113 Consequently social structure, universe, or mesocosm refers to the social/political/religious/scientific framework of the structure of European society.

For the Lutherans we need to know what Luther himself rejected (regarding the "support structures") and what he brought in to use as supports of his own newly formed structure. One of his primary supports was Augustine. While he certainly did not accept Augustine's moderate realism, he did accept, wholeheartedly the concept of original sin. Man has no "indwelling grace". 114 Early on in his writings Luther insisted that man has, in no real sense, free will. Later on, in his arguments with Erasmus he seemed to concede that there might be some type of free will, although he never defined it. 115

This pro-Augustinian approach to the issue of man was greatly bolstered by the exposure to nominalistic thought during Luther's days at the University of Erfert (1501-

\footnotetext{
113 Such an axiology lent itself to the development of the philosophy of materialism which is at the core of what the Thomist were struggling against. JMH

114 Skinner, p. 139.

115 Ernst F. Winter, Erasmus - Luther: Discourse on Freewill (New York: Frederick Ungar Publishing Co., 1981).p. 135.
} 
1505). He had "formal training" in the via moderna from Jodocus Trutvetter and Arnold von Usingen, both former students of Gabriel Biel (1410-95) who had made the University of Tubingen a famous center of nominalist scholarship. 116 It is also quite probable that Luther came in contact with the faculty of theology at this school -- a major center for the study of the devotio moderna, men such as Lurtz, Wartburg, as well as proAugustinian teachers. ${ }^{117}$ At the center of Ockham's philosophy and what had a powerful effect on Luther was the former's views on man, especially the issue already stated of man's inability to discern natural law and trust his reasoning capacity. 118 The combination of Ockham's powerful philosophical writings and Augustine's concept of original sin formed a very large part of the foundation of Lutheran philosophical theology.

This foundation led to numerous theories on society and its "correct" structure. The one which the Thomists found most disturbing was the issue of the "godly prince." Initially in Luther's polemics he stated quite forcibly that it would be wrong for any true Christian to resist a godly prince (or even an ungodly one). This position changed, permanently, in the 1530s when it looked like the armed forces of the Empire might destroy the Lutheran Church. Before this though he insisted that it was not relevant whether the prince acted in an evil fashion St. Paul had clearly stated that all Christians were subject to the governing authorities. ${ }^{119}$ Here the main issue, which the Thomists attempted to refute, was the assumption that the political realm of man was immediately ordained by God. Consequently, to rebel against the prince was, in essence, to rebel

\footnotetext{
116 Ibid., pp. 24-25. Biel himself was a student of John Mair (1467-1550), who had re-established nominalist thought in Paris starting in 1495.

117 Skinner, p. 25.

118 Ibid. pp. 23-25.

119 Ibid., pp. 16-18.
} 
against God. The arguments in support of this claim are rather convoluted, going as far back as Adam and the original family. Did Adam in consequence of being the head of the family possess political dominion as well? And if so, how far did that dominion extend? This in combination with other references in the Bible, such as St. Paul's mentioned above, formed the basis of a large portion of the Lutheran justification for complete nonresistance to political authority. A number of Lutherans addressed this whole issue, men such as Barnes and Tyndale. ${ }^{120}$ These two, in echoing Luther, affirmed and then expanded on Luther's original premise. To attempt any type of disobedience or resistance, especially to a tyrant, was equal to disobeying God. Why? Because the existence of such a tyrant must be that he was sent as a punishment by God. To resist would further provoke God. 121 Skinner summarizes this philosophy:

The political theories of the early Lutherans played a vital role in helping to legitimate the emerging absolutist monarchies of northern Europe. By arguing that the Church is nothing more than a congregatio fidelium, they automatically assigned the exercise of all coercive authority to kings and magistrates and in this way crucially extended the range of their powers. This in turn led them to reject one of the traditional limitations on the authority of secular rulers: they explicitly denied the orthodox Catholic claim that a tyrant may be judged and deposed by the authority of the Church. Secondly, they introduced a new note of passivity into the discussion of political obligation. By insisting that all the powers that be must be treated as a direct gift of God's providence, they committed themselves to saying that even tyrants rule by divine right, and that even when they do manifest wrong it must still be blasphemous to oppose them. They thus withdrew the other traditional limitation on the authority of secular rulers: they rejected any suggestion that the law of nature may be used as a touchstone for condemning or even questioning the behavior of our superiors. ${ }^{122}$

As already stated, this attitude changed completely after 1530 . By this time Luther, Melanchthon, Osiander, and, "many of their most prominent followers suddenly changed their minds, and argu[ed] instead that any ruler who becomes a tyrant may be lawfully

\footnotetext{
120 Ibid., pp. 66-68.

121 Ibid., p. 70.

122 Ibid., p. 73.
} 
and forcibly opposed." 123 This about-face eventually led to the revolutionary political ideologies of the latter half of the sixteenth century. 124

These two ideas, man's fallen nature and his inability to access and utilize natural law (if it even existed), as well as the godly prince theory, were what the Lutherans brought to the intellectual battlefield of the early sixteenth century. Now we need to move on and discover what role the humanists played in this battle, as well as the Machiavellians.

Humanitas, from which the terms "humanism" and "humanities" stem from was originally used by Cicero himself as a translation for the Greek paidiea, meaning roughly education and culture. The humanists of the Renaissance did not compose, as it sometimes seems, a coherent group with a specific purpose. We often think of the humanists as being the defenders of free thought and progenitors (to some degree) of modern political (democratic) thought. This is only partly true. We may have the Marsillio Ficinos and the Erasmus but, on the other hand, we have the Machiavellis and the Sepulvedas. These last two were the main concern of the Thomists.

Desiderius Erasmus (1469-1536) was born in Rotterdam. In the early part of his career he was actually favored by the Thomists, even the great Vitoria himself. 125 But this came to a rather abrupt end after the conference of theologians at Valladolid in 1527. There were two significant heresies that Erasmus supported. First that there should be a new and thoroughly analyzed translation of the Bible and that it should be made available

\footnotetext{
123 Ibid., p. 74.

124 Ibid.

125 Ibid., p. 141.
} 
to everyone. Second, he suggested significant education reform, both for the laity and especially for the clergy, whom he felt needed to have a better grasp of the Bible.

But if he was an enemy of the Catholic Church he became eventually no friend of the Lutherans also. ${ }^{126}$ What he had been attempting to do was find a common middle ground for both sides, and in the end upset them both. But Erasmus, for all the trouble he seemed to have caused in the eyes of Rome, was not of that "group" of humanists that scared the Thomists. This second group belonged to a whole different category They had views about political society quite similar to the Lutherans, something that the Thomists were most concerned to refute.

The two primary examples of this branch of the humanists were Juan Gines de Sepulveda (1490-1573) and Niccolo Machiavelli (1469-1517). Both men rejected the via antiqua notion of natural law, both as an ontology and as a guiding principle in political life. 127

Sepulveda studied the humanities at Bologna. He also received his theological training there. He became a leading exponent of Spanish colonialism. His main efforts were to defend the "legal and moral right to carry on their policy of enslaving the local Indian inhabitants." $128 \mathrm{He}$ argued, using a statement directly from Aristotle that there were some men who were "slaves by nature."

Sepulveda presented this argument in person at the Council of Trent and, more notoriously, at a special conference by Charles $\mathrm{V}$ at Valladolid in 1550 to consider the justice of the Spanish conquests in the New World. His thesis was somewhat difficult for

\footnotetext{
${ }^{126}$ For instance review the Ernst F. Winter translation of the Erasmus/Luther, Discourse on Free Will.

127 Skinner., pp. 142-143.

128 Ibid.
} 
the orthodox Jesuit and Dominican theorists to oppose, since it was based on an appeal to the Politics of Aristotle, an authority which they generally held in the highest reverence. Nevertheless, they clearly regarded it as essential to repudiate Sepulveda's way of defending the ethics of Empire. They evidently felt some concern about the heretical overtones of the argument, especially its reliance on the quasi-Lutheran contention that any genuine political society must always be founded in godliness. And they were no less genuinely opposed, on purely humanitarian grounds, to the shocking human consequences which had already followed from the fact that the argument was in practice becoming universally accepted. 129

What Aristotle had specifically said, when he said it, and under what historical conditions it was stated, were not nearly as important as the fact that he did say it. There was no better way to prove the legitimacy of slavery then by claiming the source of inspiration for the Thomists and to a lesser extent the Dominicans too. ${ }^{130}$ The clash between Empire and Church stemmed from an old wound: who was the ultimate overseer of this world? With the rediscovery of Africa and the new discovery of the Western Hemisphere the last great struggle by the Catholic Church to make policy for the State, or at the least have a significant say in those policies played out in the new colonies.

The Church wanted desperately to make a new and impregnable stronghold against the rise of Protestantism. Luther had shattered the unity of Christianity in Europe, and it was the hope of Church and State (i.e. Spain and Portugal) to re-establish some form of unity in the New World. Of course the motives were different, drastically so, for each

129 Ibid.

${ }^{130}$ Ernest Barker, The Politics of Aristotle (London: Oxford University Press, 1958). pp. 9-13., (1253b 1254b32). 
group. For the Crown, the Indians seemed to be a nearly ready-made source of incredibly cheap labor. If they could be turned to Christianity, this labor pool would become a reality.

The treatment of the native people by both was barbaric, to say the least. So much so that a Dominican priest, Bartoleme de Las Casas (1474-1566), who had originally started out his career as a missionary following along in such brutal practices,suddenly became repulsed by them and spent the rest of his life defending the native people both in the Americas and in Spain. 131

The arguments put forth by Sepulveda with regard to why the Indians were worthy of becoming chattel were several. He insisted that the Indians lacked reason. Also they did not have a "recognizable" political structure. Lastly, they were, heathen. Sepulveda's arguments set the tone for racist theories for the next three and a half centuries. The Thomist counter-argument also broke ground. Not only did they appeal to natural law in the Indians defense, but the basis for appeal to natural rights appears here also.

The first argument, regarding a lack of reason on the part of the Indians, was rather easily dismissed by Vitoria simply by employing the definition of "unsoundness of mind" as co-equal to Sepulveda's "lack of reason". If the Indians were truly unsound of mind, then they would not be able to function as individuals, let alone in any social context. Since this was not the case the lack of reason argument flies out the window. ${ }^{132}$ Being

131 Skinner., pp. 170-171. Las Casas went to the Americas in 1502 and after a sudden change of heart in 1514 refused to take part in the vicious treatment toward the Indians. He retired for a time to his Order and then returned to defend the Indians. He finally went home to Spain in 1547 to plead their case at the conference of Valladolid in 1550.

132 James Brown Scott, The Spanish Origin of International Law (Washington, D.C., Georgetown University, 1925) 
unbelievers also does not legitimize the use of force by the Spanish to strip the Indians of their land and their sovereignty over that land and their own lives. Vitoria is arguing here that the Indians have a natural right to their life and liberty, and that those rights are based in natural law, which are applicable to all humanity, regardless of condition. The only yardstick with which to measure others by is that they behave in a recognizably human manner, individually and collectively. For Vitoria the Indians do not have to be Christians to be protected. They simply have to have the capacity to be Christian, which for him means human being in every sense of the European definition of the word.

Although the initial argument for the Indians rests on natural law, the vast majority of the cases for the Indians follows the more focused questions of natural rights. Sepulveda would argue that the Spanish have the right to use force against the Indians because they have resisted the Spanish and resisted also the missionaries efforts, thus resisting the Pope. But the Thomists fire back that since the Indians are pagan they are not necessarily under the rule of the Pope or the Spanish, and, consequently they have a right to refuse such rule. To the charge that they have no genuine political authority because they are barbarians the answer comes back that whether they have faith in Christ or not is irrelevant to their ability to have a recognizable form of political society, and that the Indians have the right to such a society because they are, first, creatures of God.

But if Sepulveda and his backers were of great concern for the Thomists, then Machiavelli and his writings were of grave matter. It was Machiavelli who, in a particular materialistic twist, took the "crowbar" Ockham and later Luther had made the 
center of their theology, namely the inherent evil of Man, and used it to open Pandora's box. 133

Machiavelli posed for the Thomists the most "insidious and dangerous threat." 134 The center of this threat lay in Machiavelli's writings, where he suggests that in the matter of whether or not the prince should act justly the only true concern should be to preserve the state. Machiavelli, with some slight reservations, felt that Christian morality could very well be, if actually practiced, a liability for the prince. Of course, the appearance of possessing such morality was advantageous. For Machiavelli the prince does not have to subject himself to the "herd morality." 135 He rejected the effeminate aspects, as he saw them, of Christian ethics of humility and a love of suffering. 136

This does not mean that Machiavelli had any intention of counseling widespread immorality. He was perfectly well aware that a morally degraded and decadent nation is doomed to destruction; he lamented the moral condition of Italy as he saw it and he had a sincere admiration for the civic virtues of the ancient world. It is perfectly true that he says in the Discourses that the Christian exaltation of humility and contempt of the world has rendered Christians weak and effeminate; but he goes on to say that the interpretation of the Christian religion as a religion of humility and love of suffering is an erroneous interpretation. 137

In a corrupt and decadent society in which man's natural badness and egoism have more or less free scope, where uprightness, devotion to the common good, and the religious spirit are either dead or submerged by license, lawlessness and faithlessness, it is only an absolute ruler who is able to hold together the centrifugal forces and create a strong and unified society. Machiavelli was at one with the political theorists of the ancient world in thinking that civic virtue is dependent on law; and he considered that in a corrupt society reformation is possible only through the agency of an all-powerful lawgiver. ${ }^{138}$

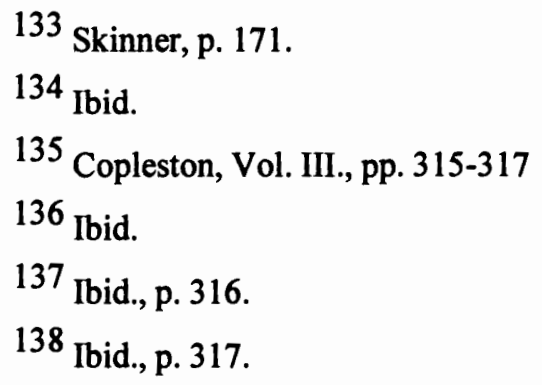


Regardless of his reasoning Machiavelli was advocating a position taken eighteen hundred years before by some of the historical characters found in Plato's dialogues. Although Machiavelli is often painted in the same hue as Thrasymachus of the Republic, he is more a mixture of Callicles (Gorgias), Glaucon, also found in the Republic and Antiphon, a sophist and contemporary and rival of Socrates. 139 The latter, as well as Callicles, were men who felt that putting on the correct public appearance -- in order solely to retain one's standing and forge ahead with one's plans -- was perfectly legitimate. Glaucon, on the other hand, wanted Socrates in the Republic to prove such a position wrong. The argument between "conventional" justice and "natural", the latter being best described as "might makes right" is what opens up the Republic.

To call forth natural law in a society on the verge of becoming more materially wealthy than any of the ancient kings could have dreamed of would have been difficult

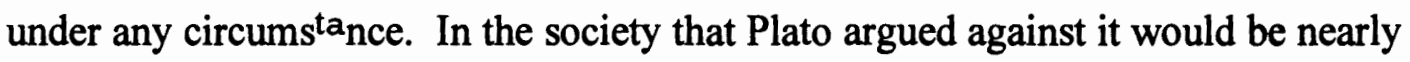
impossible. Natural law, as a working entity, had been destroyed by nominalism. The emergence of the phs perfectly legitimate. Glaucon, on the other hand wanted Socrates, in the Republic to prove such a position wrong. The argument between "conventional" justice and "natural," the latter being best described as "might makes right" is what opens up the Republic.

Of course Machiavelli was not so two-dimensional. He was not an advocate in the extreme for a monarchial despotism. He did believe in the ideal of a republican form of government. He believed that the people, despite his lack of respect for their "herdness" were better judges than despotic princes. What he introduced, and what caused such a stir

$$
\begin{aligned}
& 139 \text { Taylor., Plato, pp. 270-271. } \\
& 140 \text { Taylor, Plato, pp. 270-271. }
\end{aligned}
$$


was the concept of power politics. By this I mean that he stripped away the thin veneer (even during this period of corruption) of the "godly prince" persona. He pulled back the facade of civility and said, essentially, "this is who you (the prince) really are; this is the world in which you live -- therefore this is what you must do to succeed, to preserve the State."

Perhaps it was not so much what Machiavelli himself was trying to accomplish with his writings, as what was made of them -- what they led men to believe and act on. Perhaps this also is what the Thomists were most concerned about. Certainly the Huguenots of France would agree. They blamed the massacres perpetrated against them as being inspired by Machiavellian policies set into motion (at least partially) by the daughter of the man to whom Machiavelli had dedicated The Prince. ${ }^{141}$ This is what the Thomists feared certainly; the devolution in the mind of the people of the inherent nobility of Man, regardless of the Fall. For the Thomists, Machiavelli said simply this: "we are animals in our very nature; let the strongest survive." Man was essentially a very clever beast. It was the basement of the philosophical foundation of Lutheranism without the restraints of the fear of God, let alone the fear of upsetting the conventions of acceptable social and political behavior.

Lutheranism, Machiavellianism, and Humanism (in many respects) were the three great dragons facing the Thomists and everything they stood for essentially, the via antigua. Their attacks on these three must be seen, I feel, in this light. Even though there is certainly a great deal of defense of the Catholic Church by the Thomists, there is as much, if not more, defense for the ancient non-materialistic concept of the cosmos. 


\section{CONCLUSION}

It was the threat that Machiavelli posed to the Thomists that also caused the Thomist to realize that their response to this threat, and to the whole of such an underlying philosophy, was no longer adequate. 142

As several of these writers perceive, however, it was no longer very realistic to respond to the growing threat of "Machiavellianism" by simply reiterating their basic belief that, as Suarez repeatedly puts it in his attack on Machiavelli, the dictates of natural justice "form the only possible materials for true civil law," so that, "there must be nothing in the law which directly overturns equity or natural justice". To rest content with this response, as Ribadeneyra in particular seems to recognize, is to ignore the implications of the fact that two rival political moralities were by now confronting each other in every commonwealth of late sixteenth-century Europe. One was the natural-law theory, which Ribadeneyra takes to be "supported on God himself and on the means that he with his paternal providence reveals to the princes". The other was the theory of "Machiavelli and the politiques (los politicos), with its impious exhortations to our rulers to imitate both the lion and the fox." As Ribadeneyra begins by conceding, the difficulty is that between these "two political ways of thinking" there is virtually no common ground, since the truth of the one entails the falsity of the other, and each is claimed by its exponents to provide the only correct analysis of the moral standards to be applied in political life. The implication for the defenders of the natural-law theory was clear: if they were to succeed in answering the Machiavellians, they would need to move beyond the repetition of their own assumption; they would need to bridge the gulf between the two moralities, and attempt as it were to defeat the Machiavellians with their own weapons.

It would seem that the shift in attack by the Thomists, while certainly appearing sound had, in the end, not succeeded. By this I mean that the "infection of Machiavellianism" became a permanent element of the European body-politic. The Thomists argued that there may be numerous times when the overriding concern for a prince is the maintenance of the state. But to assume that Machiavelli had provided the best strategy for such an endeavor would be a mistake. Ribadeneyra insists that the 
Page 62

doctrine of ragione di stato was insane. 143 The problem was that there was no longer any access to natural law. They did not know how to counter these arguments. Why?

143 Ibid. 


\section{CHAPTER IV}

\section{THE MUTATION OF NATURAL LAW}

In most of the histories that I have read concerning our European heritage there is, as I have stated in the introduction, and underlying assumption of an evolution in thought. But is this actually the case? Certainly, the focus on the Renaissance has almost exclusively portrayed Europe pulling away from a more restrictive, intellectually confined, and perhaps even spiritually moribund period, a slump if you will. The very terms "Renaissance" and "Enlightenment" show us how we view the historical period we claim to be the intellectual and political ground from which America sprang.

The issue here is not that great advancements did not come about during the Renaissance or the Enlightenment. It also is not that some rather ugly things came out of the same periods. The issue is why have things come to be as they are? Even more how do we judge the progress of our civilization? Are we locked into our own axiology to such an extent that we cannot see clearly the best course?

These questions are not out of place here. Indeed they are the same questions that many minds were pondering over during the Renaissance. The Thomists undoubtedly asked them. It should be remembered that the Thomists were not thorough backers of the Pope. They did not approve of the actions of the colonists in the New World. But still, were these four men, these Thomists, locked into their mesocosm? Is that the reason that they were unable to answer Machiavelli? Here I think the answer is yes, with the 
qualification that these men had the best of intentions in trying to counter the destructive forces that they were encountering.

Their first major problem was William of Ockham. While they were not nominalists by any means in their espoused philosophy they were nonetheless hopelessly caught in the grip of nominalist thought. Nominalist teachers were to be found in schools all over Europe. You will remember that Luther himself was influenced by them at the University of Tuberg.

Nominalism was in many respects the chief enemy of the Thomists, and if they were aware of it they never addressed it directly. Yet it stood as a major support structure for each of their enemy's philosophies. Nominalism was a philosophical bulldozer that cleared the way of any remnants of the via antiqua of any ability for Plato's natural law to ever be put into practice. It was nominalism that unleashed two forces that Plato had battled in his day and now the Thomists struggled against. The first, as we have already seen, was the development of the philosophy of materialism. The second which had been emerging for sometime was the cult of individualism. In the past six centuries natural law has been shaped primarily by these two forces.

Again and again throughout my research I have been led back to William of Ockham and the development of nominalism. If there is one central pivot-point where we can clearly see the axiological forces at work it is with Ockham's theories and their growing acceptance.

Many who have studied the Middle Ages have spoken of William of Ockham as someone who brought a revolution in human thought. He completely destroyed the 
Aristotelian concepts of the Universal, Species and Genus (Aristotle's version of Platonic Forms). He did this by employing his "razor" eliminating everything which could not be proven to really exist, i.e. to physically exist. Part of his development of his razor was influenced by the fact that the Scholasticism of his time was often hopelessly boggeddown in mind-numbing details. Beyond this they would be arguing about what would today seem absurdly trivial and unprovable speculations literally how many angels could dance on the head of a pin. Ockham was seen to be the emancipator of the European mind. He brought things back down to earth. 144

We have already spoken of how William of Ockham gave focus to the physical world, how he showed the gaping holes in the metaphysics of the Scholastics, and consequently the Aristotelian-Platonic philosophies. Along with this refocusing of the European mind on the physical world came the emergence, via Ockham's writings, of the long-dormant mesocosm of individualism. It was Ockham, who, according to most scholars set Europe free from the "overlay of an Oriental type of spiritual despotism." 145

He set in motion the forces that would bring the individual to the forefront. He began the banishment of Platonic reasoning. He was the progenitor of empirical science. He showed theologically how natural law did not exist, and that even if it did exist, man has no real access to it, due to our fallen nature. And yet, despite this he was one of the very first to speak of natural rights. In order to understand what happened in Europe from the Renaissance even to the present day it is necessary to understand just what changes William of Ockham brought. Ockham has often been treated as a revolutionary. He is

\footnotetext{
144 Richard Tarnas, The Passion of the Western Mind (New York: Ballantine Books, 1991) p. 202.

145 Joseph Campbell, The Masks of God: Occidental Mythology (New York: Penguin Books, 1982) p. 509. Also see Tarnas, pp. 116-117, and 165-167.
} 
recognized for laying the foundations of via moderna. But he did much more then that. In his "freeing" of the European, he did more than lead the way in casting off the suffocating spiritual despotism. But he did not help to create the modern Europe. He essentially brought to the forefront of European consciousness the European axiology. This axiology gives great focus to the physical world as well as the importance of the individual. These central elements were to a significant degree muted by the nonEuropean axiology of the Catholic Church. The emergence of this axiology in itself would not have upset Plato. But the natural tendency for humans to move to the extreme edge of the spectrum after having been forced to suffer the other extreme would cause Plato alarm. This axiology in particular lends itself very well to the development of materialism and individualism.

William of Ockham then was not a revolutionary. He was above all else a conduit for the reemergence of the European axiology. The real subjugation was not the individual soul to the political manifestation of the Church, but rather the isolated soul to the conscience of the collective soul. Ockham put that one soul on par with the whole of the collective Church. The One has the natural right to challenge the Many, but more pointedly, that the One had the right to assume to be regarded just as important as the Many. This was Ockham's accomplishment, along with laying the groundwork for the emergence of the empirical sciences.

\section{Nominalistic Thought During the Renaissance}

William of Ockham released the force of nominalism, which with surprising quickness swept through the universities of Europe. Nominalism effected, initially, the 
fields of theology and philosophy. But the ripples of nominalism spread further to other fields of human inquiry. It ended up serving as a major pillar for the emerging empirical sciences. And, as it tore at the concept of natural law it simultaneously opened the avenue to natural rights. Ockham opened this rift with his denial, on the one hand, that man has access to natural law, ${ }^{146}$ and, on the other, with his fight with the Papacy in support of the rights of the Franciscans and their order. ${ }^{147}$ The rift he created, between natural law and natural rights, between the via antiqua and the via moderna (which he essentially created) only continued to grow.

Those who took up nominalism began to apply it broadly. It should be noted that Nominalism as it was taught up to the Renaissance was not what we would call a skeptical philosophy, or purely materialistic. All of its expounders were Christian in their outlook. All believed in God and in the revelation of God as reported in the Bible. But their internal convictions could not help them see that their own nominalist arguments would eventually lead to the questioning of these very convictions by others. It was gradual of course. All through the period of the Renaissance the vast majority of European intelligentsia would not dismiss the Christian revelation. Empirical science was just taking hold, and even though the Church would continue to censure men such as Galileo until near the beginning of the 1700 s, the new science continued to attract young minds away from the matter of the Church to a newer revelation.

We've already gainew some idea of how nominalism brought about the philosophy of materialism by widely eliminating the Platonic concept of Forms and bringing all

146 If there actually is such a thing. Ockham, as has already been discussed found it difficult to believe that God would need an intermediary realm to assist him in dealing with the human world. JMH

147 One of the reasons that Ockham may have dismissed natural law was to prevent the Papacy from making an appeal to it. JMH 
attention to bear on the purely physical. How then did nominalism bring about such a focus on the individual, thus creating, in effect an emerging ideology of individualism? Again it was not an immediate shift from the "spiritual despotism" that Campbell speaks of to a reverential treatment of the idea of the individual human being. Many forces were unleashed by nominalism to bring this about.

The emergence of courtly love in literature, with its emphasis on the all-compelling heart and the individual quest to follow its promptings was one such force. Again, science began to radically reshape how European's saw themselves in relation to the universe. As science pushed back religion as the vehicle of explanation the superstition and dogma once seen (to some degree) as methods to gain the favor of God were replaced slowly with the image of the universe-as-machine and the philosophy of materialism began to assert itself. Man would now attempt to control the machine via the emerging sciences. 148

At the same time the increasing shift, even before Martin Luther, of the concept of the Christian-as-his-own-priest produced another psychological pillar for the emerging ideology of individualism. The individual believer could only hope to attain God's grace by developing a personal relationship with God; the idea that any intermediary (priesthood/Pope) could intercede for man was the height of arrogance. 149 The individual soul was no longer bound, as Campbell would have put it, to a large socio-

\footnotetext{
148 There is certainly no end to literature from the Enlightenment onward that makes reference to mankind's ascending nature, gaining greater and greater control of Nature, gaining godlike powers. JMH

149 Skinner, pp. 22-25. Among various Pre-Lutherans were men such as Johann Wessel Gansfort (c. 141989) who gained much of his views from the already existing Brethren of the Common Life, who incidentally Erasmus studied with as a young boy (and as he added, not by his own choice).
} 
spiritual structure a mere brick in the wall. Now he stood alone under the shafts of heavenly light (or hellish?) able to be seen in his uniqueness.

William of Ockham was, of course, not the sole source for setting off all the forces that would contribute to the slow emergence of individualism. But what he set in motion, and how he did it were unique. Would Europe have taken a different course without Ockham? Sure. But nominalism would still have come about. There were others, not as brilliant as Ockham, but just as determined who were also coming to the same conclusions.

\section{The Effects of Nominalism During the Renaissance}

The question then is how did nominalism effect the three forces that the Thomists set themselves against? Nominalism effected each of the three: Luther's Reformation, Humanism and Machiavellianism. The Thomists were not just concerned with the immediate significance of these three, but just as much with the direction they would take European civilization.

If we accept the standard view of the late medieval period as a time of rejection of the spiritual despotism (or the beginnings of the rejection) we can then view Luther's revolt, Humanism and Machiavellianism as the real emergence of the European mesocosm. The development of the philosophy of materialism and the cult of individualism tended to serve the needs and interests of each of these forces in different ways. But it did allow them to all share in common the fundamental contention that the physical world was real. And what is real is of real value. 
The struggle then between the via antiqua and the via moderna then was the battle over defining reality. The Renaissance, seen in this light, was a period flux, of crisis, as emerging forces struggled to tear free of the old definitions given by the Church and those who served her. Various forces had specific goals and ideologies. Consequently, there were differences in how they went about this separation, as well as how they attempted their new definitions of reality.

The Reformation, Humanism, and Machiavellianism (as well as empirical science) all focused on physical existence as essentially the only existence. It is not relevant that some believed in a life after death with the Return of Jesus Christ. It would still be the physical world, remade yes, but physical nonetheless. At the other end of the spectrum, Machiavelli, and those who felt themselves to be his ideological descendants, were little concerned with the life-hereafter. Their concern was to obtain and secure what they could of this world now. It was the beginning of realpolitik. The Humanists fell all along the spectrum between these two. The fourth force, science, would be both an enemy and a friend to the other three at various stages of their development. For the Humanists the philosophy of materialism took numerous shapes. If we were to pick out the most predominant it would have to be the emphasis on Man. Man would become again the measure of all things. The rebirth of the humanitas in combination with the powerful new sword of the physical sciences tore away at the old superstitions and prejudices that were 
repressive to the human spirit, yet at the same time a whole new cloak of myths were beginning to be woven. 150

Individualism is inextricably woven into this new cloth. From the focus on the individual's salvation as well as the single Christian soul as its own priest, to the implications of Machiavelli's philosophy that the individual must look after his own concerns first (even if raised to the term "enlightened self-interest") individualism was threaded all through the emerging forces. Here too science played a critical role in support of this new value-structure. The European discovered that the world was not at the mercy of angels and demons but operated by a set of predictable laws that did not vary. If humans did not understand something we could discover how it worked. We were no longer at the mercy of invisible forces that had to be appeased. We could begin to control nature to suit our needs. The "I" no longer had to revolve around the larger Cosmos; slowly but steadily it became apparent that the Cosmos (or at least our portion of it) could be bent to the wants and needs of the "I". 151

\section{CONCLUSION: STANDING AGAINST THE WORLD}

This is what the Thomists, Vitoria, Suarez, and the rest faced. It was recognized, at least in part, that simple appeal to the via antiqua, natural law, and a rational God would

\footnotetext{
150 It seems that in the past thirty years or so science has spent as much time correcting old assumptions and "myths" that earlier science had created as it did in establishing new theories. Especially with the growth in quantum physics Western society has had to once again question its long held assertions of what constitutes Reality. Indeed there has been some recent scholarship to indicate that some of Plato's speculations on Creation, including the core of his concept of Forms may be closer to the truth of the recent discoveries in quantum physics than much of the scientific discoveries made in the intervening two millennia.Also see Ken Wilbur, ed., Quantum Questions: Mystical Writings of the World's Great Physicists (London: New Science Library, 1984). There is a chapter by Heisenberg wherein he mentions how near Plato's views were to modern conceptions in physics.
}

151 Tarnas, pp. 282-284. 
not suffice in holding back this flood. ${ }^{152}$ The Thomists were already at a considerable disadvantage, despite their brilliance.

Their first disadvantage was the Scholastic method of written argument. It was exhaustive in the analysis of detail and exhausting to read. 153 One of the things that the humanists disliked so much and rebelled against was this method of intellectual "hairsplitting" and communication.

An even greater disadvantage was that, despite the fact that no Thomist would readily admit to accepting nominalism as a philosophy, they were, nonetheless deeply affected by it. They had aligned themselves of course with Thomas Aquinas and Aristotle. And while they continued to make appeal to the via antiqua, to a rational order to the universe and a rational Lawgiver (God), they were trapped. William of Ockham had destroyed the Aristotelian concept of Forms, upon which natural law rested. The Thomists could not effectively make appeal to the realm of Forms as the source of natural law, at least not in any systematic sense. This left them making appeal to it as a long-standing tradition as a cornerstone of the via antiqua. They could call upon the names of Socrates, Plato, Aristotle, Plotinus, and Cicero, to name only a few, but in a very skeptical world appeal to the ancients was fast losing credibility.

The greatest disadvantage that the Thomists had was that they would not or could not recall Plato. By this time of course the dialogues of Plato were available (if just recently). Neo-Platonism was quite the rage in Europe, especially Northern Italy. But it was a superficial Plato -- one used to bolster emerging ideologies and theories. The

152 Skinner., pp. 171-2.

${ }^{153}$ As this student will positively testify. JMH 
Thomists, perhaps prejudiced by Aquinas' acceptance of Aristotle's criticism of Plato, as well as Ockham's apparent victory over the idea of universals did not reach for the source of the via antiqua. They did not call upon Plato's vast analysis of the demise of a society and the remedies to heal it. No one at that time, least of all them, really saw the systematic thought that Plato had brought to bear on this issue. Instead, Plato's dialogues were picked apart piecemeal and either used to prop up emerging socio-political theories or later on used to indict Plato himself and various elements of his paidiea that made up the political plank of one group or another.

So the Thomists were unable or unwilling to call upon what would have been their most powerful intellectual weapon. There were no great Platonic minds at that time that could formulate a powerful antidote to combat the evils of materialism and individualism. Plato had seen these forces at work in his time and had witnessed their dissolving effect on his civilization.

So, how did Plato counter this disease? We have seen his definition of the term nature and how it relates to natural law. But how did Plato deal with the issues that confronted his brothers-in-spirit eighteen centuries later? That will be the focus of the final section of this paper. 


\section{CHAPTER V}

\section{THE CONSTANCY OF NATURAL LAW}

What can be said then of the history of natural law in Europe over the past twentyfive hundred years? Given the source of natural law, i.e. Socrates and Plato and their wide-spectrum definition of the term nature and comparing this to how we find it defined by the time of the Renaissance, we would have to conclude that it retained just a shadow of its initial Platonic form. Yet we in the West claim Plato and his philosophy as our heritage. 154 Were the Spanish Thomists' fears correct? It is clear that their concerns stretched far beyond the more narrowly defined interests of the Church. What created such anxiety for them was the same for Plato: the substitution of Truth for truths, the relative for the Constant, and the imaginary for the Real. They feared that the structure of society would be rebuilt using these unreliable replacements. What they fought against did become the reality of the writings during the Enlightenment and thereafter. The idea of modern capitalism that nations behave essentially as individuals do -- which was used by Adam Smith and others to explain why economics is the vehicle of change, became a main pillar of modern democracy. Coupled with this was the shift from the emphasis on natural law to natural rights. The magnitude of this shift cannot be exaggerated. The psychological realignment was, and still is, staggering. The individual went from being a part of society, with a role to fulfill in it, to being the recipient of what society could give to that individual. Natural rights was a vehicle for discovering and then protecting access to those things deemed of value by individuals. And while the implications of what this

154 For instance the United States Constitution rests on the idea of natural law, on certain inalienable rights. 
would all eventually mean may have not occurred to the Founding Fathers it has become increasingly obvious since that time.

The tragedy of the struggle of the Thomists was that their greatest ally was someone that they rejected. The Thomists recognized the fundamental philosophies of Machiavellianism, Luther's Reformation, and Humanism as a threat to the long-term stability of civilization. It was the same threat that Socrates and Plato had faced. Plato had developed a countermeasure to this unbridled focus on the material and the individual. What he was unable to do, as is attested by him in the Seventh Epistle, ${ }^{155}$ was to find an adequate laboratory to test his ideas.

In reality the true enemy of the Thomists was a member of their own Church. The battle that they had tried so hard to win had already been determined a century and a half before they were born. William of Ockham had set the course of the intellectual war that they would engage in and the Thomists were confined to those rules. What would have happened had they had Plato?

\section{Platonic Answers}

If we view natural law in an architectural manner rather than the standard evolutionary one, we can see that the original plans were altered drastically. As I stated at the beginning of this paper, there has always been an assumption that Europeans as a people and a civilization must have evolved or progressed from the time of our

155 The events in this letter took place, according to Plato, about the year 388, when he was approximately forty years of age. See Jaeger, v.III., pp. 197-199. 
intellectual forefathers, the Greeks. We have assumed as a society that simply because we have made technological progress, or that our laws seem more "humane" in comparison to other countries, somehow we are farther along the line of historical development. 156Plato would measure the progress of society by the definition he gave for a healthy civilization. This would be the concept of justice we have seen in the Republic, as well as the definition of nature discussed earlier. He would undoubtedly be confused at the paradox between greater efforts at establishing human rights and the horror of the twentieth century. Have we progressed? Or evolved? In certain respects we have, undoubtedly. But we may very well appear to Plato as an adolescent which is quite physically mature, and shows evidence of intellectual brilliance, yet is unable to establish mature relationships with anyone because we still do not really know ourselves. For Plato we would still be struggling to become real human beings. We need to measure how natural law has changed from the original design of Plato. Viewing Plato's conception of natural law as a blueprint for a great edifice we can compare the original design with what we have found to be some of the major changes in the Renaissance. This is what the Thomists were attempting to do. They were insisting that what was occuring in Europe was not simply a turning away from the via antiqua; it was the abandonment of right reason. In their eyes Europe was stumbling off into a road of deadly self delusion. Nominalism had also brought a shift, a profound one, in the concept of Law. From ancient Greece until the time of Thomas Aquinas law (and here we are referring to natural law), was seen as the rational ordering of things, of right reason. William of Ockham dismissing both natural law and its foundational structure in universals (as Aristotle termed Plato's Forms) gave a wholly new definition of law. It was Augustinian

\footnotetext{
156 If there is any doubt that we still find ourselves morally superior simply witness the furor over the (as yet to occur at the time of this writing) probable caning of the young American man in Singapore for the ten day of deliberate vandalism. Many Americans, especially the media portray Singapore's insistence on carrying out the punishment, as well as the punishment itself, as barbaric.
} 
in its nature. Law was no longer equated to right reason. Instead law was now synonymous with obligation. 157

How would Plato have viewed all this? We can only draw from his own circumstances Despite the fact that a city-state is not a nation, it is, in many significant ways a good microcosm of a nation. It is necessary for us to turn to Plato because he is the origin of natural law and so much of what we still consider to be the foundation of our own laws. We need to briefly examine his original design, his paidiea. 158 Specifically we will review what Plato had to say about the philosophy of materialism and the ideology of individualism.

Plato, too, had to struggle against the forces that advocated a philosophy of materialism as well as an ideology of individualism. ${ }^{159} \mathrm{He}$ saw in them the harbinger of social devolution, of chaos. He answered the challenge that all three posed. It is not possible to give anything more than a brief overview of his answers to each of these areas. I think if this is successful that we will discover in a much more streamlined fashion, what the Thomists were attempting to accomplish in their answers to their opponents.

157 Oakley., Ch.XV., p. 74. Also see Jaeger., v.III., p. 194.

158 The term paidiea means, roughly, education. But it means a lot more then that, and indeed Plato expanded greatly on the term. The root of paidiea is pais which means child.

${ }^{159}$ I am using the term ideology and occasionally cult throughout this paper in the widest possible sense of the word. It is something less than a fully developed philosophy, but certainly something more than a passing fad or phase. JMH 
For Plato materialism in all its manifestations as a competing philosophy was the foundation of all the evil of society. ${ }^{160}$ He referred to both the lust for wealth as well as those who advocated the idea that the physical world was "reality entire." 161 Why did Plato see this philosophy as such a disastrous course to follow?

This issue was very real for Plato. He was not an ivory tower sort. He lived in the midst of the decline of Periclesian Athens. It was a time of tremendous flux. He had witnessed his family and friends became caught up in this turmoil, some of them quite willingly, feeling that this was what was best for them and the family. This confusion of purpose, both for the individual and society was what eventually led, in Plato's mind, to the death of his mentor. 162 Plato then was not developing his philosophy in a rarefied atmosphere -- rather it was born of necessity. ${ }^{163} \mathrm{He}$ was anxiously concerned with trying to heal the disease of the human soul which had led Athens and much of the Greek world toward an abyss.

Plato was, in essence, warning Athens of the evils of a philosophy that tried to restructure the rational order of nature by placing the individual at the center of things. If we give a cursory glance at the central elements of what Plato listed as key to the eventual destruction of society they are the same elements that European civilization has

\footnotetext{
160 "The love of money is the root of all evil things." (1 Tim. 6:10) This statement of Paul's was a voicing of an already old wisdom of the Stoic school. It should be noted that this statement does not say that money is the source of evil. See also the Laws 870 and 913; cf with the Republic 562b2-b6.

161 Theat. 155e; Sophist 246a.

162 Jaeger., v. II., pp. 4-5 and 27-29. Also see: Barker., pp. 107-108.

163 N.G.L. Hammond, A History of Greece (Clarendon Press, Oxford. 3rd edition., 1986). pp. 442-43. Also see: Barker., p. 105.
} 
held to be the basis for its advancement and greatness. ${ }^{164}$ Material well-being and prowess over the physical world are central to that view.

Yet if we examine the Republic carefully we see in Socrates analysis of the devolution of society two central themes. As he leads Glaucon to witness the downward spiral the two maladies become increasingly apparent: the undue focus on material life and well-being and individual rights. 165

Plato recognized that both these elements when carried to excess, pull and tear at the very fabric of society. He also recognized that a set of laws, no matter how well conceived could not stem this devolution. As in so many other areas he was a genius in psychology. His analysis of this devolution of the state is a double analysis because it concerns the human soul also. In such a case an external remedy (laws) will at best only slow the spread of this infection. But law can only go so far, even if it is infused with a spirit of morality and solid rational design. If the agents of the law, as well as the recipients of it, are not themselves infused with the same spirit even the greatest of efforts by a Pericles will not suffice. 166

Thus education (paidiea) became for Plato the vehicle to rebuild the individual and consequently society. This instruction must be for both the mind and the soul.The soul

\footnotetext{
164 There is no place in the dialogues of Plato that I have found yet, (and I would add that I am far from having read all of them) that equates terms such as destruction, devolution, degradation, etc., with a literal ceasing to exist. Certainly he must have felt that this could occur. The Greeks were already well aware at that time that there were civilizations that had ceased to exist. But I think he means that society in a devolved condition would not really be a human society - if by human we mean a striving to achieve what was best in humans - a society that actively educates and mirrors the attributes that he felt made us something more than animals. JMH

165 Jaeger., v. II., p. 331-36. Also compare the Republic 545 - 564.

166 Jaeger., v.II. p. 238.
} 
must be shown the path to true happiness. ${ }^{167}$ For Plato wealth alone, the possessions of objects, cannot lead to true happiness because the physical life is transitory. The world is constantly changing in its conditions. ${ }^{168}$ Wealth too is transitory. To base happiness on something that could be gone tomorrow can in the end only lead to sorrow. 169

As stated earlier the need for wealth is not disputed by Plato. ${ }^{170}$ It a normal part of the life of society. It is the insistence of wanting more, of not being satisfied that is the problem. Satisfaction, or the recognition that a balance has been reached is a perception of the rational element of the soul. 171 Plato did not of course recognize in his dialogues any formal axiology as has been described in this paper. But he understood the basic pattern of how a society with such a value system would operate. His analysis of the Athenian condition was not a description of a passing phase. He witnessed a fundamental shift in the very nature of his society, as Socrates had before him. He feared, as the Spanish Thomists did nearly two thousand years later, that society was changing, for the worse.

Such stress on excess wealth breaks down the fabric of the community. In the early stages of such a social phenomenon the upper classes continue to hold the wealth. Eventually, though, the taste of wealth trickles down to the middle classes. Concessions

167 Letter VII 335d5; also Gorgias 470e.

168 Plato did not believe that the world was in total flux and that the appearance of any permanence was simply an illusion. But he did recognize that physical existence was essentially transitory. There was generation and degeneration. He was not confused by surface Change - He did not believe in flux at the foundational level of existence. JMH

169 Certainly the allegory of the Cave, with the full implication of Plato's interpretation of it (regarding paidiea) would indicate this. See: Jaeger, v. II., pp. 291-94.

170 "Wealth" should not be thought to mean here a small fortune, but rather the monetary means to live in at least moderate comfort. Laws 870a-c; Republic. 591d-e.

171 For Plato the soul was composed of three elements. The highest is spirit, followed by reason and lastly appetitive. See: Jaeger., v. II., p. 241. 
are made by the upper classes to the middle in order to retain power. This does not last though, as the poor begin to see that the "pie" is being carved up and nothing but the scraps are being left for them. ${ }^{172}$

This is the beginning of the fraying of the social fabric. As this fabric is being stretched and pulled in different directions clumps of threads begin to appear separated from the whole, and then even more fraying takes place and eventually individual threads appear alone. Common sense tells any observer that such a garment is doomed. It may continue to be worn for some time, but it will inevitably disintegrate. The individual threads cannot last under the strain and begin to snap at an increasing rate. Even if this degeneration takes place only in a certain section of the cloth and is not noticed, it will ultimately affect the entire piece.

One element of this fraying or separating out is the ever-increasing demand by more and more sub-groups for specific rights. This is only natural. On one hand these, groups see (to some degree) that their survival depends on trying to secure these rights, due to the social decay. On the other hand this decay begins when, as Plato asserts, the appetitive nature of the soul goes unchecked, or worse is encouraged. These groups (and later individuals) are taught that this is the way to "get ahead" in the world. The upper classes, thinking to appease this ever-growing appetite of the lower classes, feed it. Of course this is disastrous since there is no end to the appetite. This process continues and reaches a point that Plato described (in constitutional terms) as the development of democracy. 173

172 Republic 551d; Laws 735e - 736a.

173 Republic 543 - 562. This is the chapter that Plato outlines the devolution of society through an analysis of the various constitutions that come about when material wealth is made the center of focus for the individuals of the society. 
Finally, from the stage of democracy we devolve to the last stage, which is tyranny. ${ }^{174}$ Here Plato makes reference to one man and his ability to effect the population as a whole. But tyranny here is not restricted simply to the autocrat. It is linked completely to the now totally exposed appetitive nature of the masses. There is no unity of society. There is unity in fear of punishment and in fear of being deprived. It is the fear of one individual essentially alone having to survive as best he can. It is, in reality, the world that Thrasymachus seems to long for in the beginning of the Republic. 175 Here might makes right and only the strongest survive.

In all this we must remember that Plato had a double purpose. His first and primary concern was to discover what justice was in the human soul, and in order to discover this he needed to look at the state, which is far larger and, as he says, easier to examine. 176 So the examination of the degeneration of the state, painted broadly, was an investigation into the devolution of the soul. 177 It is not possible for the state to be just if the attribute of justice is not actively developed in each citizen's soul. Justice is not a static concept, as we've come to understand in examining Plato's definitions of nature. 178

Society is as much an organism as any individual. 179 In reality, there is, according to Plato, no significant difference in this analogy. The health of both the collective and the individual are interconnected. If one or the other is diseased the other cannot remain unaffected. Just as a cancer begins in one individual cell as a mutation and eventually

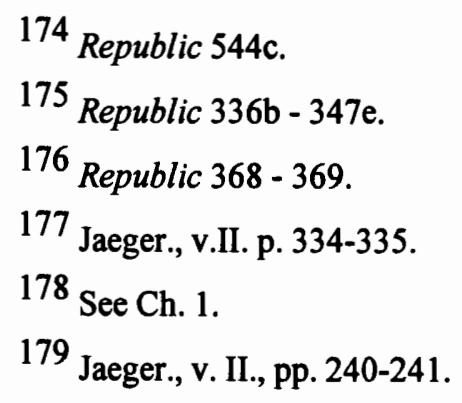


spreads to destroy an entire area of the body, so goes the cancer of the soul. If one individual infects another soul with a false paidiea the mutation has begun. Even though the foot of an individual is not directly attacked by, let's say a cancer of the liver, eventually the body will degenerate, and the foot is destroyed just as surely as if it had been attacked directly. There is no escape from such a cancer.

The psychological role played by the ideology of individualism is a very interesting one. We see now how the individual with little or no constraint, with no real understanding of his responsibilities to the body of society, can play the role of this cancer cell. Correspondingly, the body of society suffers as greater and greater energy has to be used to deal with the growing cancer cells. ${ }^{180}$

For Plato the above condition is devastating. But it should not be assumed that he found overly strict, ascetic-like conditions any better. ${ }^{181}$ For him there was a need for balance. The balance begins with the individual soul. Too much leniency and the soul becomes soft, prey to the undiminished demands of the appetitive nature that exists in every human. Too harsh a discipline and the joy and creativity of the human spirit is crushed.

Paidiea was the answer that Plato insisted on. Education of the soul. When the soul was led to discover what its true nature consisted of -- what would lead to true and lasting happiness, then society would become stable and begin to mature into a truly great civilization. A lack of real paidiea would eventually lead to disaster.

180 Jaeger., 334-336, Rep. 557a-e.

181 Despite the fact that in the Republic Plato focuses a lot of attention on various elements of Spartan society he did not believe that a monk-style life was the answer for these weaknesses. JMH 
The third area where a better understanding of Plato could perhaps have helped the Spanish Thomists was the issue of law. Although there was a significant difference in the concerns of Plato and the Thomists there were also some strong similarities. For the Thomists there was the concern that the philosophy of law was being transformed into something that was alien to human nature. This was, as mentioned earlier, a fundamental change from the long-held concept that law was equivalent to right reason to the idea that law was equal to obligation. 182

Plato did not see law as obligation. The best that law could be was an imperfect reflection of reason. Law did not contain justice. The thought that a society could be safely set up based on a constitution was naive. Unfortunately, it was also a necessity since finding truly wise and just leaders was exceedingly difficult. 183 Plato recognized on several levels that laws (constitutions) were inadequate to the task of governing society. Laws are static and therefore not able to properly address the natural flux of a human society. 184

On a more metaphysical level laws are inadequate because they are at best frozen images of the attribute of justice. Law cannot contain justice; it can, at best, be a landmark to assist us in recalling to our minds what justice is and where it exists. But this is often not the case. We become fixed on the object (law) and forget that it is suppose to

182 Obligation came from the Augustinian concept of Original Sin. Man was not capable, according to St. Augustine to participate in his own redemption. Ockham agreed with this and elaborated on this. If there even was such a thing as natural law man had no real access to it because of his fallen nature. Therefore the law revealed in the Bible, and also positive law should be obeyed because humans had no real ability to distinguish justice. To rebel against a law then was to rebel against God. Luther it will be remembered was definitely influenced by Nominalists during his university days.

183 Laws 875a-d.

184 Statesman 294b. 
be a conduit to help us bring forth justice. ${ }^{185}$ So for Plato law is a container only. If we cannot bring out through conscious design the philosopher-kings of the Republic, then we must construct the most perfect and beautiful constitution (container) possible. But even here Plato is concerned with paidiea first. The law will not succeed if it is simply meant to cause fear in people. If the law is to really be effective it must educate. It must lead people, as much as is possible, to happiness. 186

While the law must contain the threat of punishment, this punishment is primarily to bring the wandering soul back onto the path. Nothing is ever learned through compulsion. Perhaps on the surface it is to mollify the teacher, but as soon as it is not needed (essentially to survive) it is left behind. 187 The law must guide and help every citizen. Therefore it must be very well designed. It must not simply herd individuals along like cattle. The people must, to the degree that each one can, come to understand the law. 188

Much of the Laws is occupied by discussions of education - the first two books and the seventh contain nothing else. But that is not the only importance of the book for the subject of paidiea. From Plato's point of view the entire work is devoted to constructing a powerful system of education. Its relation to the problem of paidiea is most clearly set forth in a passage of the ninth book, which takes up and develops a theme already introduced in the fourth. This is the comparison of a bad legislator with a slave's doctor, hurrying from one patient to another and prescribing treatment quickly and dictatorially without giving reasons or making a complete diagnosis, simply by following the practice of others or working on his own experience. Compared with him the free man's doctor looks like a philosopher. He talks to his patients as if they were his pupils whom he had to help to conscious understanding of the cause of some phenomenon. The slave's doctor would not understand that detailed and comprehensive method of instruction; if he heard his colleague doing it, he would say, "You are not treating your patient; you are teaching him as if you wanted to make him a doctor instead of curing him." All contemporary

\footnotetext{
185 Plato says this in various ways throughout his middle and later dialogues; e.g. Laws $711 \mathrm{e}-712 \mathrm{a}$.

186 Laws 743c.

187 Republic 536e.

188

Laws 951a-b.
} 
legislators are on the same level as the slave's doctor. They are not real healers, because they are not teachers. And that is the purpose of Plato in the Laws." 189

So in conclusion, Plato saw the law as a vehicle (a less-than-perfect one) to attempt to achieve his goal -- the just state. The state can only be just if its citizens are just. If there cannot be a philosopher-king, which would be the best, then the law would have to suffice to educate the population. Law could be a tyrant also, especially in a time of social decay as the rulers use more and more laws, with harsher punishments in an attempt to bring back order. But in actuality this is not law, but rather an extension of the ego of the ruler. Just as good law, designed by reason is an extension of the mind and soul of a righteous ruler.

\section{CONCLUSION}

This is a brief view of how Plato would have answered to the challenges that faced the Spanish Thomists. Plato himself, and before him Socrates, faced very similar threats. Both attempted to make natural law a major foundational pillar of society. For both natural law was not some vague abstract term that referred to grand ideals. But the philosophy of materialism would make it seem so. For both Plato and the Thomists the times that they lived in were chaotic. They recognized, though, that the forces operating around them were not simply the normal flux of human interactions. Both saw in the new ideologies facing them a grievous harm about to be played out on civilization. It was unrecognizable to most men because most men are short-sighted, especially in such troubled times. Ambition, as well as the need to simply survive, makes them so.

189 Jaeger., v. III. p. 215. 
It was not that either feared the total destruction of civilization per se; I don't think they were capable of grasping that possibility, except by some divine force perhaps. But the other consequence was just as bad the slow decay into a barbaric state. Both saw that humans could rise to glorious heights; or they could sink to a level below that of animals. What determined which course would be taken was the education of the soul.

The Thomists had not been able to see many of the connections that Plato had seen. This is due, it would seem, to a lot of historical baggage. There were those in Plato's time that continually hearkened back to the distant golden age of Homer; Plato had to dispense with their nonsense also. But the Thomists had a great deal more history to deal with, not to mention a far more complex civilization.

To call forth natural law in a society on the verge of becoming more materially wealthy than any of the ancient kings could have dreamed of would have been difficult under any circumstance. In the society that Plato argued against it would be nearly impossible. Natural law, as a working entity, had been destroyed by nominalism. The emergence of the physical sciences only helped to bury it further. The psychological elements of mankind's fallen nature, reinforced by Luther's Reformation, pushed natural law even farther away.

But it was the restructuring of what Plato would call the natural order of human society that banished natural law to a realm of platitudes. The shift in the position of the individual from being a part the whole, which revolved around the Good (or God either way Plato would have had no problem) to being at the center of things was the beginnings of a social cancer that Plato feared most. The European, in an effort to justifiably throw off a suffocating blanket of decaying and outworn beliefs, threw out the 
baby with the bath water, so to speak. In an effort to gain freedom, few people, except the Thomists and some others, stopped to ask where would this freedom lead? Freedom from oppression is something Plato would have encouraged. But a vacuum cannot be created without something trying to fill it. In the haste to be free the beauty and excitement of discovering a new mesocosm, in all its glory, must have been dazzling. The reign of the individual, with a myriad unique wonders coming from every direction, was proof that such a revolution was good.

In such a setting natural law, as Plato saw it, with the balancing of the individual's need and that of society's simply could not hold sway, except in a very superficial manner. In areas where society's needs were absolutely critical then the rights of the individual must give way. This seemed to work, but we have seen how this supposed mechanism of Western society has only grown more confusing not less so. The first cry that is raised when some group or individual's "rights" are being threatened is this: "This could happen to you!" This fear, generated in each individual, usually unexamined, creates turmoil as society tries desperately to redefine the balance between the needs of the collective body and the individual.

Plato may well have lived in a city-state, which is very different from the superpower nation we live in today. But one thing is constant between the two, even after 2500 years; he lived with humans. Their worries and concerns, wants and desires were fundamentally the same as ours today. Of course our the day-to-day lives are vastly different, but the basic elements of being a human, and living within a society of humans, has not changed much. 


\section{BIBLIOGRAPHY}

Adams, Marilyn Mcford. William Ockham, vol. 1., Notre Dame, Indiana: University of Notre Dame Press, 1987

Barker, Ernest. Greek Poltical Theory. New York: Barnes \& Noble, 1961

Barker, Ernest. The Politics of Aristotle. London: Oxford University Press, 1958

Boehner, Philotheus. Ockham: Philosophical Writings. London: Nelson \& Sons Ltd., 1959

Burckhardt, Jacob. The Civilization of the Renaissance in Italy. vol. 1., New York: Harper \& Row Publishers, 1958

Burnet, John. Early Greek Philosophy. London: Adam \& Charles Black, 1945

Carre, Meyrick H. Realists and Nominalists. London: Oxford University Press, 1950

Cassirer, Ernst. Translated by Mario Domandi. The Individual and the Cosmos in Renaissance Philosophy. Philadelphia: University of Philadelphia Press, 1972

Copleston, Frederick, S.J., A History of Philosophy. 3 vols. Garden City, N.Y.: Image Books, 1985

Cornford, F. M. Before and After Socrates. London: Cambridge University Press, 1968

Cornford, F. M. Plato's Cosmology. Indianapolis, IN., The Bobbs- $\quad$ Merrill Co., 1937

Courcelle, T. Late Latin Writers and their Greek Sources. Cambridge: Harvard University Press, 1969

Desjardins, Rosemary. The Rational Enterprise: Logos in Plato's Theaetetus. Albany, N.Y.: State University of New York Press, 1990

Duhem, Pierre. Edited and Translated by Roger Ariew. Medieval Cosmology. Chicago: University of Chicago Press, 1985

Dunn, John. The Political Thought of John Locke. Cambridge: Harvard University Press, 1969

Figgis, John Neville. Political Thought from Gerson to Grotius: 1414-1625. New York: Harper Torch Books, 1960 
Page 90

Finnis, John. Natural Law and Natural Rights. Oxford: Clatendon Press, 1980

Gierke, Otto. Translated by Ernst Barker. Natural Law and the Theory of Society. Boston: Beacon Press, 1957

Goodman, Anthony and Mackay, Angus. Editors. The Impact of Humanism on Western Europe. London: Longman Press, 1990

Hamilton, Bernice. Poltical Thought in Sixteenth Century Spain. London: Oxford University Press, 1963

Hamilton, Edith and Huntington Cairns. Ed. The Collected Dialogues of Plato. Bollingen Series LXXI. Princeton, N.J., Princeton University Press, 1989

Hammond, N.G.L. A History of Greece to 332 B.C. 3rd ed. Oxford: Clarendon Press, 1986

Haydn, Hiram. The Counter-Renaissance. New York: Grove Press, 1960

Hollinger, David A. In the American Province. Bloomington, Indiana: Indiana University Press, 1985

Hughes, Ted. Shakespeare and the Goddess of Complete Being. New York: Farrar Straus Giroux, 1992

Jaeger, Werner. Early Christianity and Greek Paidiea. London: Oxford University Press, 1969

Jaeger, Werner. Paidiea: The Ideals of Greek Culture. Translated by Gilbert Highet 3 vols. New York: Oxford University Press, 1986

Knowles, David. The Evolution of Medieval Thought. London: Oxford University Press, 1962

Kristeller, Paul Osker. Renaissance Concepts of Man. New York: Harper and Row Publishers, 1972

Kristeller, Paul Oskar. Renaissance Thought. New York: Harper and Row Publishers, 1955

McGrade, Arthur S. The Political Thought of William of Ockham. Cambridge: Cambridge University Press, 1974

Myers, Eugene A. Arabic Thought and the Western World. New York: Frederick Ungar Publishing Co., 1964

Oakley, Francis. Natural Law, Conciliarism and Consent in the Late Middle Ages. London: Variorum Reprints, 1984

Patterson, Richard. Image and Reality in Plato's Metaphysics. Indianapolis, Indiana: Hackett Publishing Co., 1985 
Pegis, Anton C. Introduction to St. Thomas Aquinas. New York: Modern Library, 1948

Reale, Giovanni. Plato and Aristotle. Edited and Translated from the fifth edition by John R Catan. Albany, N.Y.: State University of New York Press, 1990

Scott, James Brown. The Spanish Origin of International Law: Lecutres on Francisco de Vitoria (1480-1546) and Francisco Suarez (1548-1617). Washington, D.C.: Georgetown University, 1925

Scott, James Brown. The Spanish Origin of International Law: Francisco De Vitoria and His Law of Nations. Oxford: Clarendon Press, 1934

Schmitt, Charles B., and Quentin Skinner. The Cambridge History of Renaissance Philosophy. Cambridge: Cambridge University Press, 1988

Sigmund, Paul E. Natural Law in Political Thought. Cambridge, MA: Winthrop Publishers, 1971

Skinner, Quentin. The Foundations of Modern Political Thought. 2 vols. Cambridge: Cambridge University Press, 1978

Stein, Peter. Legal Evolution. Cambridge, MA: Cambridge University Press, 1980

Suarez, Francisco. On Formal and Universal Unity: De Unitate Formali et Universali. Translated by J.F. Ross Ph.D Milwaukee, WI., Marquette University Press, 1964

Tarnas, Richard. The Passion of the Western Mind. New York: Ballentine Books, 1991

Walker, Williston. A History of the Christian Church. New York: Charles Scribner's Sons, 1970

Weinreb, Lloyd L. Natural Law and Justice. Cambridge: Harvard University Press, 1987

Williams, Rowan. Arius: Heresy and Tradition. London: Darton, Longman and Todd, 1987

Winter, Ernst F. Trans. Erasmus-Luther: Discourse on Freewill. New York: Frederick Ungar Publishing Co., 1981 